Universidade de São Paulo

\title{
Fluorescência no Diagnóstico da Cárie
}

\author{
Augusto César Ribeiro Figueiredo
}

Dissertação apresentada à Área Interunidades em Ciência e

Engenharia de Materiais, da

Universidade de São Paulo, para obtenção do título de Mestre em Ciências e Engenharia de Materiais.

Orientador: Prof. Dr. Vanderlei Salvador Bagnato

São Carlos - 2003

USP/IFSCISBI

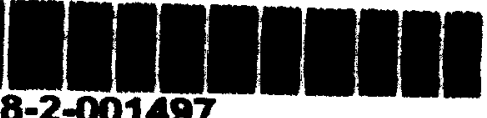

8-2-001497 
Figueiredo, Augusto César Ribeiro

F475f Fluorescência no Diagnóstico da Cárie / Augusto César Ribeiro Figueiredo. São Carlos, 2003.

Dissertação (Mestrado) - Escola de Engenharia de São Carlos / Instituto de Física de São Carlos / Instituto de Quimica de São Carlos - Universidade de São Paulo, 2003.

Área: Ciência e Engenharia de Materiais.

Orientador: Prof. Dr. Vanderlei Salvador Bagnato.

1. Fluorescência. 2. Laser. 3. Cárie. 4. Diagnóstico. I. Titulo. 


\section{Ciência e Engenharia de Materiais}

Caixa Postal 369 - CEP 13560-970 - São Carlos-SP - Brasil

Tel: (0xx16) 2739589/Fax: (0xx16) 2739777

e-mail: wladerez@if.sc.usp.br

STUNiDA

MEMBROS DA COMISSÃO JULGADORA DA DISSERTAÇÃO DE MESTRADO DE AUGUSTO CESAR RIBEIRO FIGUEIREDO, APRESENTADA À ÁREA INTERUNIDADES CIÊNCIA E ENGENHARIA DE MATERIAIS, UNIVERSIDADE DE SÃO PAULO, EM 28/03/2003.

\section{COMISSĀO JULGADORA:}

Prof. Dr. Vanderlei Salvador Bagnato ( Presidente) - IFSC-USP

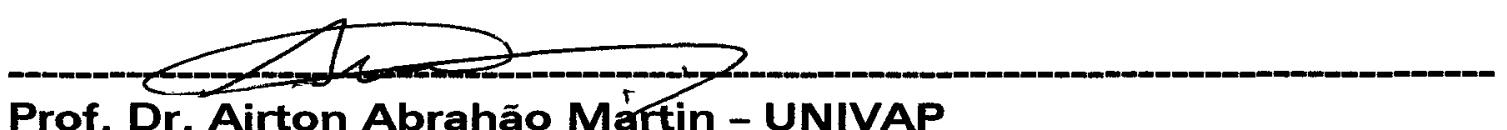

Prof. Dr. Airton Abrahão Màrtin - UNIVAP

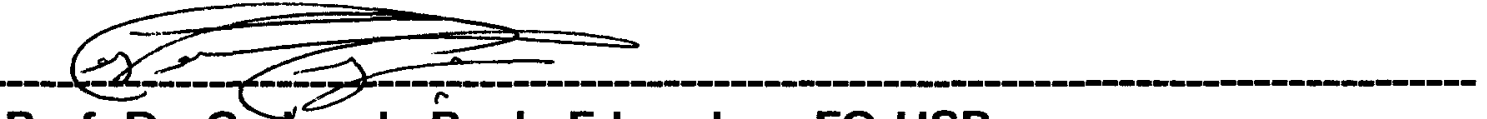

Prof. Dr. Carlos de Paula Eduardo - FO-USP 
Aos meus pais Kléber e Zélia e aos meus avós Laerte e Lígia, pelo amor, oportunidade e sacrifícios, e a minha esposa Carolina e ao meu filho Vinícius pelo amor e compreensão. 
Ao Prof. Vanderlei, meu Orientador, pela incansável e valiosa instrução e principalmente, pelo apoio e confiança depositados em $\mathrm{mim}$, sem os quais esse trabalho não teria sido realizado.

Ao Márlon e Carolina, pela paciência e colaboração.

Ao Raimundo e Beatriz, e por todas essas pessoas que compõem essa maravilhosa familia, pelo apoio e confiança transmitida.

Aos Professores Hernandes, Casteletti, Águida, Gilberto Goissis, Waldek, Tomaz Catunda por colaborarem com a minha formação.

Aos amigos do Laboratório Rosane, Carla, Juliana, Paulo, Clóvis, Emílio e Claúdia.

À amiga Vitória pela amizade e sua colaboração nos experimentos.

À Lilian pela amizade e colaboração na parte de informática.

À Cristina pela ajuda nos experimentos e a correção dos trabalhos. 
Aos amigos Luciana, Reinaldo e Chiara pela amizade e por todo apoio dispensado.

Ao amigo Cláudio por toda disposição.

Aos Pacientes por sua confiança.

Ao Daniel e Lino pela elaboração e correção do software para calcular a área da fluorescência.

Aos amigos Cazuza, Célia, Daniel, Sara, Elias e Renata pela amizade.

À minha Tia Letícia por sua paciência e amor.

À todos os meus Tios e Tias por acreditarem em mim.

Aos técnicos e amigos Evaldo, André, Cássio e Tico pelo inestimável apoio técnico.

À Roseli do Pronto Socorro por ajudar a armazenar os dentes.

A Glaúcia, Isabel, Waderez, Samira, Érica e Cristiane por sua ajuda na parte burocrática.

Aos colegas do grupo de óptica pela ajuda com os problemas. 
Aos amigos Marcel e Brás por sua amizade, apoio e colaboração.

Ao amigo Luis Humberto pelo ensinamentos CM1.

Ás funcionárias da Biblioteca pela disposição em solicitar os artigos em outras bibliotecas

Aos Professores da Universidade Federal de Uberlândia por minha formação acadêmica.

A todos os Professores que direta ou indiretamente contribuiram com esse trabalho.

À ABO - Regional de Uberlândia pelo apoio na aquisição dos dentes.

A FAPESP (programa CEPID) pelo suporte financeiro.

Ao CNPq bela bolsa de estudo.

A USP e UNESP pelas portas sempre abertas 


\section{SUMÁRIO}

LISTA DE FIGURAS

i

LISTA DE TABELAS

iv

LISTA DE ABREVIATURAS E SIGLAS

v

LISTA DE SIMMOLOS

vi

RESUMO

vii

ABSTRACT

viii

I. INTRODUÇÃO

1

II. REVISÃO DA LITERATURA

6

II.1. CÁRIE DENTAL

6

II.2. MÉTODOS CONVENCIONAIS DE DIAGNÓSTICO DA CÁRIE 10

II.3. MÉTODOS ÓPTICOS NO DIAGNÓSTICO DA CÁRIE 
III.1. DETERMINAÇÃO DA FIGURA DE MÉRITO A PARTIR DO ESPECTRO DE FLUORESCÉNCIA 
V. CONCLUSÃO GERAL

VI. REFERÉNCIA BIBLIOGRÁFICA 
Figura 1 - Diagrama esquemático do sistema de fluorescência

Figura 2 - Laser de He-Cd (esquerda) e Nd:YAG dobrado (direita) 30

Figura 3 - Laser de $\mathrm{HeNe}$ 30

Figura 4 - Monocromador

Figura 5 - Leitura de autofluorescência do esmalte sadio excitado com $532 \mathrm{~nm}$

Figura 6 - Esquema de aquisição e processamento do espectro

Figura 7 - Aprovação do Comitê de Ética em Pesquisa

Figura 8 - Espectros de fluorescência para excitação com $632 \mathrm{~nm}$. O primeiro pico (esquerda) é o pico elástico cuja energia corresponde ao comprimento de onda de excitação (pico elástico) e a segunda região (direita) é a fluorescência (região inelástica) 
Figura 9 - Espectros de fluorescência para excitação com $442 \mathrm{~nm}$. O primeiro pico (esquerda) é o pico elástico cuja energia corresponde ao comprimento de onda de excitação (pico elástico) e a segunda região (direita) é a fluorescência (região inelástica)

Figura 10 - Espectros de fluorescência para excitação com $532 \mathrm{~nm}$. O primeiro pico (esquerda) é o pico elástico cuja energia corresponde ao comprimento de onda de excitação (pico elástico) e a segunda região (direita) é a fluorescência (região inelástica)

Figura 11 - Distribuição da razão do pico elástico pelo pico inelástico (FM1) para o esmalte, dentina sem cárie e dentina cariada quando excitado com $442 \mathrm{~nm}$ 44

Figura 12 - Distribuição da razão do pico elástico pelo pico inelástico (FM1) para o esmalte, dentina sem cárie e dentina cariada quando excitado com $532 \mathrm{~nm}$ 45

Figura 13 - Distribuição da razão do pico elástico pelo pico inelástico (FM1) para o esmalte, dentina sem cárie e dentina cariada quando excitado com $632 \mathrm{~nm}$ 46

Figura 14 - Contraste para FM1 48

Figura 15 - Valor médio e desvio padrão para FM2 em cárie, dentina e esmalte 52

Figura 16 - Valor médio e desvio padrão para FM3 em cárie, dentina e esmalte 52 
Figura 18 - Contraste para FM3

Figura 19 - Aparelho comercial Diagnodent@ utilizado no diagnóstico de cárie por fluorescência 63

Figura 20 - Laser de Er:YAG (TWINLIGHT - Fotona Medical Lasers, Slovenia) 69

Figura 21 - Escore do Diagnodent® por energia de irradiação com laser de Er:YAG 
Tabela II - Valores das médias das razões com seus desvios padrões para cárie, dentina e esmalte utilizando FM2

Tabela III - Valores das médias das razões com seus desvios padrões para cárie, dentina e esmalte utilizando FM3

Tabela IV - Contraste para FM2 para excitação com 442, 532 e 632nm

Tabela V - Contraste para FM3 para excitação com 442, 532 e 632nm 


\begin{tabular}{ll}
$\mu m$ & micrômetro \\
CPO-D & dentes permanentes cariados, perdidos e obturados \\
ECM & eletronic caries monitor \\
Er & érbio \\
FM & figura de mérito \\
FOFO & fiber-optic fluorerscence observation \\
FOTI & transilumunação por fibra óptica \\
Hz & Hertz \\
LED & light emitting diode \\
mJ & milijoule \\
mm & milimetro \\
mW & miliwatt \\
$\mathrm{N}$ & newton \\
nm & nanômetro \\
OCT & optical coherence tomography \\
PS-OCT & polarisation sensitive optical coherence tomography \\
QLF & quantitative light/laser fluorescence \\
YAG & segundo \\
& unidades arbitrárias \\
\hline
\end{tabular}


$\lambda \quad$ comprimento de onda

$<\quad$ menor que

$>\quad$ maior que 


\section{RESUMO}

A incorporação de novas ferramentas na área de saúde tem promovido uma grande atividade interdisciplinar. A Odontologia tem sido uma dessas áreas beneficiadas com a incorporação de novas tecnologias, principalmente, na área de detecção de cáries. Atualmente, a tecnologia para uso da fluorescência no diagnóstico da cárie utiliza apenas um comprimento de onda no espectro da fluorescência, relacionando com a intensidade, para a determinação da presença ou ausência de tecido cariado. No entanto, deve ser analisado o espectro de fluorescência como um todo e não a fluorescência em um único ponto, pois todos os comprimentos de onda na fluorescência contêm a informação mais precisa sobre a existência ou não de cárie. Neste trabalho descrevemos uma maneira de processarmos a fluorescência para diagnosticar com mais precisão a existência de cárie, para isso, estudamos o comportamento da fluorescência do esmalte e dentina sadios e dentina cariada através de duas formas de processamento dessa fluorescência, sendo primeiramente através da razão do pico elástico pelo pico inelástico e a razão da área inelástica pela área elástica. Utilizamos dentes que apresentavam esmalte e dentina sem cárie e uma face com dentina cariada que foram excitados com três fontes de laser com $442 \mathrm{~nm}, 532 \mathrm{~nm}$ e $632 \mathrm{~nm}$. Foi possivel determinar que os três comprimentos de onda foram eficientes na detecção de cárie, porém quando os tecidos foram excitados com $442 \mathrm{~nm}$ e $632 \mathrm{~nm}$ os resultados apresentaram os melhores contrastes, além disso,. apresentamos um segundo experimento, onde medimos a fluorescência do esmalte sadio com o aparelho comercial Diagnodent $($ antes e depois da irradiação com o laser de Er:YAG e mostramos que o aparelho mostra erros nessas medidas acusando cárie em esmalte sadio irradiado com o laser, isso identifica um problema quando a fluorescência é captada em um único comprimento de onda. 


\begin{abstract}
The introduction of new tools in medicine has promoted an important interdisciplinar activity. In Dentistry, the improvement induced by this new technology is mainly observed at caries detection. Until now, the fluorescence procedure for caries detection is based on the investigation of only a specific region of the fluorescence spectrum. From this analysis the presence of caries or healthy tissues is inferred. However, all the fluorescence spectrum must be evaluated and not only a small part of it. The collected information will be important to the caries diagnosis. In this work we propose two ways to process the fluorescence spectrum in order to obtain a more accurate diagnosis. In this way, we study the fluorescence behavior of health enamel and healthy and decayed dentin. The fist way to process the fluorescence here proposed is obtained by the ratio of inelastic peak and elastic peak and the second one, the ratio of the inelastic and elastic areas. It were investigated human teeth with healthy enamel, decayed and healthy dentin surfaces at the same sample. The fluorescence was induced by three lasers excitation: $442 \mathrm{~nm}, 532 \mathrm{~nm}$ and $632 \mathrm{~nm}$. All the used wavelengths showed to be efficient for caries detection, however $442 \mathrm{~nm}$ and $632 \mathrm{~nm}$ presented better contrasts. A second study was performed, when the fluorescence of healthy enamel was investigated using a commercial device (Diagnodent $(\mathbb{Q})$ previously and after Er:YAG irradiation. It was demonstrated that this device can present divergent results showing a caries diagnosis for a healthy irradiated enamel surface. This result identifies a problem when a single wavelength is evaluated from all the fluorescence spectrum.
\end{abstract}




\section{INTRODUÇÃO}

A cárie representa um importante problema de saúde pública afetando uma grande parcela da população mundial, principalmente em países industrializados, pois consomem grandes volumes de alimentos feitos a base de açúcar (Featherstone; Young, 1999).

Nos últimos anos, houve uma queda no número de dentes cariados, essa diminuição na incidência da cárie é decorrente da utilização de medidas preventivas.

Com a diminuição das lesões cariosas ocorreu uma mudança na morfologia da cárie e local de incidência, diminuindo em superfícies lisas e aumentando em superfícies oclusais (Cangussu et al., 2002).

A superfície oclusal apresenta inúmeras irregularidades, ou seja, fóssulas e fissuras que facilitam a retenção de restos alimentares, bem como, bactérias e seus subprodutos (Picosse, 1983).

A detecção de cáries iniciais (manchas brancas), que possibilitaria a aplicação de medidas remineralizadoras, somente tornam-se visíveis após atingirem profundidades superiores a $200 \mu m$ (Stookey et al., 1999).

Por décadas, Cirurgiões-Dentistas têm confiado na inspeção visual, na sonda exploradora e nas radiografias para explorar as lesões cariosas em sítios 
suspeitos. Novas técnicas prometem promover maior precisão e, especialmente, a possibilidade de um diagnóstico precoce.

A cárie dental é caracterizada por uma infecção bacteriana, como exemplo os estreptococos mutans e os lactobacilos (Loesche, 1986), com capacidade para produzir ácido (láctico, acético e propiônico).

A infecção causa perda de mineral iniciando pela superficie do dente e progredindo através do esmalte e dentina até a polpa. Uma vez detectada a cavidade cariosa, a desmineralização do tecido já progrediu pelo tecido dentário por aproximadamente um terço a metade da espessura do esmalte.

Devido à anatomia do dente, as radiografias somente detectam a cárie quando está bem avançada. Nesse estágio, a opção de tratamento convencional é a utilização de instrumentos rotatórios e materiais de restauração.

Utilizando a sonda exploradora e o espelho clínico cerca de $60 \%$ das cáries não são diagnosticadas e Kairalla et al., 1997 demonstraram ainda que utilizando videoscópio (câmera intra-oral) não ocorreu aumento na precisão dos diagnósticos. Em seu trabalho demonstrou que métodos visuais (espelho plano), sonda exploradora e videoscópio somente possibilita o diagnóstico de $40 \%$ das lesões.

A sonda exploradora é um método que deve ser evitado no diagnóstico de cárie, já que quando essa percorre cáries iniciais (manchas brancas) que são passiveis de sofrerem remineralização, a sonda destrói prismas de esmalte sem sustentação, iniciando o processo de cavitação (Yassin, 1995).

O método radiográfico (radiografias bite-wing) não é um método confiável no diagnóstico de superfícies oclusais, já que as cáries tornam-se visíveis, radiograficamente, a partir do momento que atingem grandes dimensões, mas é um método útil no diagnóstico em superfícies proximais. 
Com essas falhas nos métodos convencionais, os meios ópticos, vêm ganhando espaço no diagnóstico da cárie, já que são ferramentas não destrutivas e não provocam alterações nas propriedades do tecido analisado.

Recentemente, apareceram técnicas para diagnosticar cáries através da espectroscopia de fluorescência (Featherstone, 2000). Normalmente, esses dispositivos são baseados na detecção das caracteristicas de emissão da fluorescência das substâncias presentes na superficie do dente, sendo, normalmente, essas substâncias produzidas pelas bactérias.

A espectroscopia tem, provavelmente, providenciada a mais ampla ferramenta para a elucidação da estrutura das espécies moleculares, bem como, determinar quantitativa e qualitativamente os compostos orgânicos e inorgânicos (Skoog et al., 1997). O fenômeno da fluorescência ocorre somente quando há substâncias específicas que são excitadas por um específico comprimento de onda.

Fluorescência é um importante processo de emissão em que átomos ou moléculas são excitados por absorção de radiação eletromagnética. As espécies excitadas relaxam para seu estado fundamental, liberando sua energia como um fóton (Skoog et al., 1997). Em termos simples, a luz com um comprimento de onda (comprimento de onda de excitação) é absorvido pelo tecido e reemitido em um segundo comprimento de onda maior (comprimento de onda de emissão), que representa menor energia. No processo de fluorescência a energia absorvida é sempre maior do que a emitida. $O$ fato importante é que a energia emitida é uma impressão digital dos constituintes moleculares da amostra.

A vantagem da fluorescência é que a sonda não precisa estar em contato direto com o tecido analisado, além de ser um método não destrutivo e não promover alterações nas características teciduais.

A fluorescência vem sendo estudada desde 1981 por Alfano e Yao no diagnóstico de cárie, onde observaram que os tecidos cariados e sadios 
apresentam diferenças nos espectros de fluorescência quando excitado com diversos comprimentos de onda. Os autores observaram a fluorescência com excitação nos seguintes comprimentos de onda: 350,410 e $530 \mathrm{~nm}$ observando que a fluorescência da superfície cariada apresentou menor intensidade de fluorescência e demonstraram que o espectro do tecido cariado quando foi normalizado pelo espectro de fluorescência observaram uma maior intensidade de fluorescência na região vermelha do espectro eletromagnético.

Através do estudo de Hibst e Paulus (1999) a KaVo (Biberach, Alemanha) desenvolveu um sistema que realiza o diagnóstico de cárie em superfícies lisas e oclusais utilizando a fluorescência, o Diagnodent $\otimes$. Esse aparelho opera com laser de diodo excitando o tecido em $655 \mathrm{~nm}$ e captando a fluorescência gerada pelo tecido dental e graduando com valores de 00 a 99 para determinar a possibilidade de cárie. A vantagem do aparelho é a graduação da lesão, ou seja, quanto maior o valor medido maior será a extensão da cárie. O aparelho mede o nível de fluorescência no infravermelho próximo através de um filtro e detector.

O Diagnodent $\otimes$ possibilitou uma precisão superior a $70 \%$ no diagnóstico das lesões cariosas, bem como, reprodutibilidade dos resultados (Lussi et al., 1999). Uma vantagem desse aparelho é sua capacidade de monitorar as lesões no sentido de estar havendo uma evolução ou estagnação ao longo do tempo, deixando a decisão para o profissional entre o tratamento restaurador ou preventivo. Para essa decisão é necessário que o profissional avalie, além da medida do Diagnodent $\bigotimes$ os hábitos de higiene do paciente, bem como, sua dieta. Apesar de existir um aparelho comercial, a investigação da fluorescência para determinação de cáries ainda está longe de ser considerado um assunto fechado.

Devido às vantagens encontrados no diagnóstico da cárie por fluorescência como o aumento na confiabilidade dos diagnósticos e monitoramento das lesões cariosas, realizamos investigações in vitro em dentes humanos da fluorescência 
para o esmalte e dentina sadia e para dentina cariada com a determinação de métodos de análise para obter a melhor diferenciação entre o tecido dental cariado e sadio. Usando diferentes comprimentos de onda para excitação e obtendo o espectro completo da fluorescência, foi possivel definir uma figura de mérito (FM), cujo valor pode ser correlacionado com presença de cárie. Com uma visão completa do espectro, promoveu uma melhor chance de identificar importantes aspectos relacionadas à fluorescência detectada em função do comprimento de onda de excitação.

O escopo principal deste trabalho é o de dar inicio a uma série de estudos visando observar o espectro de fluorescência como um todo ao invés de um único comprimento de onda, no processo de avaliação da cárie.

Apresentamos no Capitulo 1 uma Introdução do trabalho, onde descrevemos $o$ assunto a ser tratado, seus objetivos e finalidades e informando métodos empregados, no Capítulo 2, uma revisão da literatura sobre cárie, métodos convencionais de diagnóstico da cárie e os métodos ópticos no diagnóstico da cárie. No Capítulo 3 discutimos o Experimento I, onde analisamos o pico da fluorescência em relação ao pico de excitação, assim como, a área da fluorescência em relação à área de excitação, sendo primeiramente analisado a área total da fluorescência e depois analisamos a área parcial da fluorescência. No Capítulo 4 avaliamos o Experimento II com medidas feitas pelo Diagnodent $\circledast$ antes e depois da irradiação com o laser de Er:YAG. No Capítulo 5 é feito uma conclusão geral do trabalho. 


\section{REVISÃO DA LITERATURA}

\section{II.1. CÁRIE DENTAL}

Observou-se um declínio no número de dentes cariados nos países industrializados, esse declínio na prevalência da cárie dental, primeiramente, ocorreu devido ao largo uso do flúor em programas de saúde pública como a água de abastecimento fluoretada, aplicação tópica de flúor e especialmente devido ao uso de dentifricios fluoretados. Apesar desse declínio, a cárie ainda atinge cerca de 95\% da população (Stookey et al., 1999).

A cárie continua sendo um dos principais problemas de saúde pública, apesar do avanço que a Odontologia Preventiva sofreu nos últimos 20 anos. Essa patologia acomete grande parcela dos adultos e crianças, fazendo com que os dentes passem por processos restauradores e protéticos levando a uma agressão da polpa dental, em alguns casos, provocando a sua falência (Featherstone; Young, 1999).

Cangussu et al. (2002) realizaram um levantamento no município de Salvador, Bahia, Brasil com escolares de 12 a 15 anos, de ambos os sexos, 
matriculados em escolas públicas e particulares. Os autores encontraram um CPOD (dentes permanentes cariados, perdidos e obturados) aos 12 anos de idade de 1,44 , sendo $50,2 \%$ de dentes cariados, responsável pelo maior índice no CPO-D, seguido de $45,2 \%$ do componente obturado e 4,6\% extraídos. Já aos 15 anos de idade o CPO-D foi de 2,66, sendo os dentes obturados a maior proporção com $49 \%$, seguida respectivamente do cariado e extraido $44,9 \%$ e $6,1 \%$, sendo os molares o grupo mais atingido e observaram que a maioria das cáries tem sua maior incidência em superfícies oclusais.

As faces oclusais com suas fóssulas e fissuras, que apresentam morfologia e profundidade variadas, são superfícies extremamente susceptiveis à cárie, pois o acúmulo de alimentos e bactérias é facilitado por sua anatomia.

A anatomia oclusal dificulta o diagnóstico da cárie devido as limitações dos métodos convencionais de diagnóstico que são a sonda exploradora, espelho plano e radiografia.

Os melhores métodos no tratamento da cárie podem ser obtidos quanto mais precocemente a cárie for diagnosticada, pois pode-se evitar a utilização de métodos restauradores e favorecendo os tratamentos que permitam a remineralização das lesões, com isso, evitando a utilização de materiais restauradores.

A formação da cárie envolve a desmineralização de tecidos calcificados como o esmalte que consiste de cerca de $96 \%$ de material inorgânico por peso, $3 \%$ de água e $1 \%$ material orgânico.

O esmalte é um tecido permeável que permite trocas iônicas com o meio ambiente da cavidade bucal, particularmente a saliva. O mineral do dente é constituído de hidroxiapatita carbonatada que é muito solúvel e depois de exposto ao meio bucal realiza trocas iônicas permitindo a troca do carbonato por outros ions, sendo que o cristal formado, menos solúvel, é a fluorapatita. Esse carbonato 
substitui o fosfato na rede do cristal criando defeitos estruturais que fazem o mineral mais solúvel ao ácido (Ten Cate, 1988; Jones, 2001).

$\mathrm{Na}$ desmineralização do tecido calcificado ocorre a perda de minerais que formam a hidroxiapatita, com isso, há a formação de poros, permitindo o alojamento de produtos gerados em decorrência do metabolismo bacteriano.

O esmalte recobre toda camada externa da coroa dental que tem a função de proteger a dentina do esforço mastigatório, suportando forças de até $700 \mathrm{~N}$ e dos ataques ácidos de alimentos e de produtos do metabolismo bacteriano contando com espessuras de aproximadamente $2 \mathrm{~mm}$ na sua superficie de trabalho. (Jones, 2001).

Devido ao alto conteúdo mineral, o esmalte é um tecido muito friável, incapaz de resistir as forças mastigatórias sem sofrer fraturas. A dentina é um tecido que possui, comparativamente, maior elasticidade, com a função de dar suporte ao esmalte e compensar a sua fragilidade. Em peso, a dentina apresenta, aproximadamente, $70 \%$ mineralizada com cristais de hidroxiapatita carbonatada e seu principal componente orgânico é o colágeno. Apresenta ainda uma grande quantidade de poros (túbulos odontoblásticos) formados pela deposição de prédentina ao redor dos prolongamentos odontoblásticos, possuindo, também, alta concentração flúor e magnésio (Marshall Jr et al., 1997; Ten Cate, 1988; Jones, 2001).

A formação da cárie dental não é um processo estático que envolve apenas a desmineralização do dente mas é um processo dinâmico de des/remineralização envolvendo a tríade de Keyes (1997):

-hospedeiro

-microbiota

•dieta 
Onde, as principais bactérias são os estreptococos mutans e sobrinus e os lactobacilos. Esses fermentam os carboidratos e como resultado do metabolismo liberam ácidos que promovem a descalcificação do dente (Loesche, 1986).

Os principais ácidos liberados pelas bactérias cariogênicas são: ácido láctico, acético e propiônico (Featherstone, 2000; Jones, 2001).

Os ácidos eliminados pelas bactérias podem ser neutralizados pelo hospedeiro através da ação tampão da saliva. A neutralização ajuda no processo dinâmico de des/remineralização com os ions de cálcio e fosfato da saliva e favorece a formação da fluorapatita.

Embora, os ácidos dos alimentos possam causar desmineralização do dente a principal causa da cárie é a bactéria. As bactérias se acumulam na película adquirida do dente formando a placa dental, metabolizando o açúcar e produzindo ácidos que desmineralizam o dente provocando a cárie. A adesão bacteriana não é um processo aleatório, pois as bactérias formam colônias organizadas conhecidas como biofilme. $O$ biofilme pode ser definido como uma população de microorganismos associados com polimeros extracelulares formando uma interface (Jones, 2001).

Primeiramente, as cáries são observadas, clinicamente, como manchas brancas que ocorrem devido a uma pequena desmineralização superficial sob a placa dental. As lesões aparecem brancas devido às mudanças nas propriedades ópticas de refração do esmalte.

Ao microscópio óptico, três zonas podem ser distinguidas na lesão de cárie inicial: zona translúcida, zona escura e corpo da lesão até alcançar a superfície do esmalte (Silverstone, 1973).

A zona translúcida interna representa a primeira zona de alteração do esmalte, observável com o microscópio óptico, e foi bem estabelecido que ocorre remoção de mineral nessa zona. A zona escura representa uma área que foi 
previamente translucente, porém está agora sofrendo remineralização. Esta alteração indica a natureza dinâmica do processo carioso como uma das fases alternantes de desmineralização e remineralização, mais do que um simples processo de dissolução contínua do material. O corpo da lesão é onde a maior parte do mineral está sendo perdida e onde as mais destrutivas alterações morfológicas estão ocorrendo.

Uma importante característica da lesão cariosa inicial é que a maior parte da desmineralização ocorre em um nivel subsuperficial, de tal forma que uma camada superficial bem mineralizada permanece em posição por algum tempo. Sugere-se que essa zona superficial permanece intacta por ser um local onde, os ions fosfato e cálcio, oriundos, sejam da dissolução subsuperficial ou da placa, são reprecipitados (Ten Cate, 1988).

\section{II.2. MÉTODOS CONVENCIONAIS DE DIAGNÓSTICO DA CÁRIE}

$\mathrm{Na}$ clínica, rotineiramente, as lesões de cárie são detectadas com a utilização de sonda exploradora quando visualmente temos dúvida sobre manchas brancas ou escuras se são ou não cáries em fóssulas ou fissuras. Se o explorador prende quando uma pressão é aplicada na ponta, então o teste tátil é dito positivo para cáries como descrito por Black em 1924 (Featherstone; Young, 1999).

Porém, a sonda prender nessas superfícies não é o suficiente para detectar cáries, já que a morfologia das superfícies oclusais pode provocar diagnósticos falso-positivos, pois essas áreas apresentam fóssulas e fissuras que podem prender a ponta do explorador (Sicher, Tandler, 1981; Picosse, 1983). 
Em cáries iniciais, existem muitos prismas de esmalte sem sustentação e ao passarmos a sonda exploradora por essas lesões podemos dar inicio a cavitações, onde existem apenas manchas brancas passiveis de sofrerem remineralizações (Yassin, 1995).

Kairallla et al. (1997) avaliaram os dois métodos convencionais de diagnóstico de cárie que são o visual e o tátil com sonda exploradora, sendo que incorporou no exame visual o videoscópio com sistema AccuCam. No trabalho foi determinado que não houve diferença significativa entre esses exames, pois a inspeção visual ficou com $40,4 \%$ de acerto, o tátil com $38,5 \%$ e o videoscópio $41,3 \%$ deixando aproximadamente $60 \%$ das cáries sem serem diagnosticadas.

Radiografias bite-wing são utilizados para diagnosticar cáries nas proximais dos dentes. Essa radiografia é a base para muitas das detecções de cáries entre os dentes.

A deteç̧ão radiográfica da cárie consiste na observação de áreas radiolúcidas, áreas escuras, na radiografia compativeis com cárie. Embora, as radiografias são aceitas no diagnóstico de superfícies proximais é difícil detectar essa patologia nas superfícies oclusais em estágios iniciais, além de expor o paciente à radiação ionizante.

As lesões cariosas para serem detectadas por radiografias convencionais devem apresentar profundidade de no mínimo 300 - 500 micrômetros para poderem ser visualizadas (Stookey et al., 1999).

Uma das limitações no controle da cárie é que quando essa é diagnosticada pelos métodos convencionais já está em estágio bem avançada, isso impede a utilização de medidas conservadoras que possibilitem a remineralização dessa lesão, com isso, é necessário partir para medidas menos conservadora que é a restauração do elemento dental. 
O diagnóstico precoce da cárie tem assumido grande importância, devido à possibilidade de se reverter 0 processo patológico através de medidas remineralizadoras com flúor e medidas preventivas como o controle da placa bacteriana com a escova de dente e o fio dental para um favorecimento da remineralização da estrutura dental.

Prevenir o aparecimento de lesões cariosas nos dentes é atualmente a principal meta da Odontologia Moderna. Com o conceito de prevenir a cárie em seus estágios mais iniciais de desmineralização, essa doença exige métodos mais precisos de detecção de cárie.

Os principais métodos de diagnóstico empregados na clínica diária: exame visual, sonda exploradora e radiográfico. Porém, esses métodos são inadequados para o diagnóstico de cárie em superfícies oclusais (Tovo et al., 2000).

\section{II.3. MÉTODOS ÓPTICOS NO DIAGNÓSTICO DA CÁRIE}

A Medicina tem presenciado uma melhora nos métodos de tratamento de algumas doenças devido a incorporação de novas tecnologias.

Uma dessas tecnologias incorporadas e que tem assumido grande importância foi os procedimentos realizados com laser. Essa tecnologia está possibilitando cirurgias oftálmicas mais rápidas e mais precisas, cirurgias do sistema nervoso, quando indicados, comprovando resultados muito superiores do que outros instrumentos. O laser está sendo utilizado, também, na área de diagnóstico, conhecido como biópsia óptica.

Na biópsia óptica não é necessária a remoção de tecido para sua análise para a determinação de presença ou ausência de moléstias. Esse procedimento 
apresenta a vantagem de respostas imediatas, com isso, ganha-se tempo nos diagnósticos.

Os lasers em medicina continuam a avançar e melhorar nossa habilidade ao utilizarmos procedimentos menos invasivos com resultados benéficos iguais ou melhores e a aceitabilidade desta tecnologia é atribuida à:

- Melhores procedimentos operatórios;

- Melhor visibilidade;

- Capacidade de diagnósticos médicos;

- Recuperação mais rápida no pós-operatório;

- Ausência de infecção, pois não ocorre contato direto com o tecido

- Redução do edema;

- Melhor qualidade de cicatrização;

- Maior precisão e possibilidade de hemostasia.

A Odontologia é uma das áreas médicas que tem se beneficiado com as propriedades do laser. A Odontologia recentemente iniciou a incorporar essa tecnologia em seus procedimentos. Desde então, os pesquisadores estão descobrindo novas aplicações e indicando promessas de que os lasers logo tornarão a modalidade terapêutica de escolha.

A Odontologia tem se beneficiado da tecnologia a laser com a melhora em muitos procedimentos. O laser foi incorporado à Odontologia por Goldman et al. em 1964a, onde reportaram o uso do laser de rubi para a análise dos componentes inorgânicos do cálculo sub e supragengival, e descreveram ainda o impacto do laser na cárie dental (Goldman et al., 1964b).

Stern e Sognnaes (1964) analisaram o efeito do feixe de laser nos tecidos dentais duros e reportaram que o esmalte e a dentina sofriam cavitação quando sujeitos ao feixe de laser de rubi. 
Stern e Sognnaes (1972) têm pesquisado sobre a utilização de diversos tipos de lasers em relação à prevenção da cárie dental, afirmando em seus trabalhos que os lasers promovem uma superficie de esmalte mais resistente ao ataque de ácidos dos microorganismos, possibilitando assim, uma maior resistência às lesões cariosas.

Myers e Daniel (1991) e White et al. (1991) estudaram a utilização de diferentes tipos de lasers em cirurgias de tecidos moles intra-orais em contraste com técnicas convencionais.

Tseng et al. (1991) estudaram os efeitos do laser na redução do número de bactérias intra-sulcular em casos de doença periodontal. $\mathrm{Na}$ Endodontia o laser está sendo utilizado na redução bacteriana do sistema de canais radiculares (Myers, 1991).

Uma das grandes vantagens do laser é sua aceitação no tratamento de crianças e adultos sem a necessidade da utilização de anestésicos locais (Myers e McDaniel, 1991; Matsumoto, 1994).

O laser também é utilizado na remoção de tecido cariado (Goldman et al. 1964), na dessenssibilização de dentina hipersensível (Myers, 1991), no condicionamento do esmalte dental (Eduardo et al., 1995), na fotopolimerização de compósitos com a utilização do laser de argônio (Kelsey et al., 1989 e Brugnera Jr, Pinheiro, 1998) e no clareamento dental (Garber, 1997).

No tratamento do virus herpes (Figueiredo et al., 2002a), excisão de tecidos moles (White, Goodis, 1995), inflamação através de drenagem linfática (AlmeidaLopes et al., 2002).

Métodos ópticos vem ganhando destaque na deteç̧ão de cáries dentais, pois a desmineralização do esmalte e da dentina altera a porosidade e ocorre alterações químicas com a descalcificação e incorporação de novos produtos químicos gerados pelo metabolismo bacteriano e provenientes do meio bucal. 
Essa alteração química no tecido altera as suas propriedades ópticas, isso possibilita efetivamente $\circ$ uso de métodos ópticos, para a detecção da lesão cariosa, como Fiber-optic fluorescence observation (FOFO) (Van der Veen, Ten Bosch, 1996a), Transiluminação por fibra óptica (FOTI) (Fennis-le et al., 1998), Fluorescência (Figueiredo, Bagnato, 2002b; Figueiredo, Bagnato, 2002c; Figueiredo, Bagnato, 2002d; Figueiredo et al., 2002e), Optical Coherence Tomography (Featherstone, Young, 1999; Featherstone, 2000), QLF (Quantitative Light/Laser Fluorescence) (Hafström-Björkman et al., 1992; Angmar-Månsson et al., 1996; Shi et al., 2001), Two photon technique e PS - OCT (Polarisation Sensitive Optical Coherence Tomography) (Dichtl et al., 1999; Everett et al., 1999; Longbottom, 2000).

Zadoná (1997) pesquisou a utilização do laser de argônio no diagnóstico da cárie, o qual possibilitou uma melhor visualização do esmalte desmineralizado nas fossas e fissuras oclusais juntamente com exame de fluorescência.

Para a detecção da cárie a técnica óptica que está ganhando grande destaque é a fluorescência, pois tem possibilitado a quantificação e a monitoração longitudinal dos processos cariosos.

A Fluorescência é um processo onde átomos e moléculas são excitados por absorção de radiação eletromagnética. Essa radiação eletromagnética é proveniente de uma fonte laser que emite o fóton, sendo absorvido pelo elétron da camada de valência.

Quando o elétron absorve o fóton ele recebe energia que o faz ir para niveis superiores de energia, porém o elétron torna-se instável nesse novo nível. Para adquirir a estabilidade é necessário que o elétron retorne ao seu nível de origem. Porém, no retorno é necessário que o elétron libere o excesso de energia. Essa energia é liberada na forma de fóton que é a fluorescência. 
O fóton que excitou o elétron possui uma energia maior do que o fóton que foi emitido na forma de fluorescência, por isso, o comprimento de onda da fluorescência é maior que o comprimento de onda da fonte de excitação.

A fluorescência ocorre somente quando o elétron decai de um nível energético excitado para sua camada de valência. Se ocorrer um decaimento desse elétron em subniveis de energia ocorre liberação de energia por outras formas, como o calor.

No decaimento do elétron do seu nível excitado para a camada de valência podemos observar a ocorrência de fluorescência e fosforescência. A diferença entre esses dois processos é que o tempo de decaimento.

Na fluorescência o tempo de decaimento do elétron do seu nível excitado para o seu estado fundamental é muito menor que o tempo de decaimento da fosforescência.

Em termos simples, para ocorrer a fluorescência um comprimento de onda excita os constituintes do tecido e esse libera um comprimento de onda maior (com menor energia) do que o de excitação (com maior energia). O fenômeno da fluorescência somente ocorre quando existam substâncias específicas que são excitadas por um comprimento de onda (Skoog et al.,1997).

As principais substâncias biológicas encontradas na cárie, responsáveis pela fluorescência na região do vermelho e infravermelho próximo, são as porfirinas que possuem seu espectro de fluorescência nessa região. Essas porfirinas são produzidas pelas bactérias presentes na cárie (König et al., 1999; Longbottom, 2000; Masychev et al., 2000).

König et al. (1999) investigaram o decaimento cinético da fluorescência da cárie e do tecido dental sadio por excitação pulsada usando uma freqüência dobrada de 40 ps com laser de diodo a $390 \mathrm{~nm}$. As regiões cariadas exibiram um lento decaimento da fluorescência (com média de $17 \mathrm{~ns}$ de tempo de vida da 
fluorescência) quando comparado com o tecido sadio. Os fluoróforos (substâncias que emitem fluorescência) de longa vida presentes nas lesões cariosas emitem preferencialmente na região vermelha do espectro. O tempo de decaimento e as características espectrais são típicas de monômeros de porfirina livres de metal.

Os autores Masychev e Alexandrov (2000) sugerem que as porfirinas além de serem responsáveis pela fluorescência da cárie seriam também responsáveis pela fluorescência do cálculo dental devido a incorporação da porfirina na sua estrutura e sugerem que as porfirinas são produzidas por bactérias anaeróbias da boca, pois as concentrações dessas bactérias excedem as das áreas intactas.

O tecido quando é excitado na região do espectro vermelho apresenta fluorescência com intensidade muito baixa, enquanto que o tecido cariado apresenta alta intensidade de fluorescência (Hibst, Gall, 1998; Hibst, Paulus, 1999; Masychev et al., 2000).

Masychev et al., (2000) mostraram que a intensidade de fluorescência dependerá também da profundidade da cárie. Quando ocorrer um aumentando na profundidade da cárie haverá um aumento na intensidade da fluorescência.

Podemos observar que a intensidade da fluorescência dos tecidos sadios é bem menor que a do tecido cariado quando excitado com $632 \mathrm{~nm}$. Essa característica foi descrita por Hibst e Gall, 1998; Hibst e Paulus, 1999; Masychev et al., 2000.

Utilizando a fluorescência foi demonstrado que o tecido cariado e sadio apresentam diferenças nos espectros de fluorescência quando excitado com diversos comprimentos de onda como é o estudo de Alfano, Yao (1981), onde os autores provocaram fluorescência com os seguintes comprimentos de onda: 350 , 410 e 530nm observando que a fluorescência da superficie cariada, quando excitada com esses comprimentos de onda, apresentaram menor intensidade e 
demonstraram que o tecido cariado apresentou maior intensidade de fluorescência na região vermelha do espectro eletromagnético.

Bjelkhagen et al. (1982) irradiaram o dente com uma fonte laser de argônio em $488 \mathrm{~nm}$ e fotografaram com lentes que deixavam passar comprimentos de onda superiores a $540 \mathrm{~nm}$ em colorido e preto e branco. Encontraram que regiōes intactas do esmalte apareciam amareladas quando excitadas com $488 \mathrm{~nm}$ e as áreas cariadas apresentavam-se escurecidas.

Em 1985, Sundström et al. detectaram a fluorescência para o esmalte e dentina sadios e cariados com os seguintes comprimentos de onda de excitação: $337 \mathrm{~nm}$ (nitrogênio), 488nm (argônio) e 515nm (argônio), porém não encontraram fluorescência quando o tecido foi excitado com 633nm (Hélio-Neônio). Além disso, observaram que os tecidos quando excitados com esses comprimentos de onda, 0 tecido cariado apresenta uma intensidade de fluorescência menor que a intensidade de fluorescência dos tecidos sadios.

Van der Veen e Ten Bosch (1995) estudaram a autofluorescência da dentina antes e depois da desmineralização in vitro. Eles descreveram como a autofluorescência da dentina é dependente da desmineralização. Usaram para excitar o tecido os seguintes comprimentos de onda: $460 \mathrm{~nm}$ e $488 \mathrm{~nm}$, os espectros de emissão foram detectados em $520 \mathrm{~nm}$. Os autores avaliaram a autofluorescência obtendo uma razão do sinal emitido comparado com o sinal de referência. A autofluorescência das partes desmineralizadas foram mais fortes que as não desmineralizadas.

Hafström-Björkman et al., 1991a excitaram o esmalte bovino e humano e a hidroxiapatita sintética com $375 \mathrm{~nm}$ e não encontraram diferenças na fluorescência entre esses materiais. Além disso, observaram dois picos em 460 e $560 \mathrm{~nm}$, sendo que esses picos representam a presença de dois cromóforos diferentes. 
Hafström-Björkman et al., 1991b induziram cárie em ratos pelo sistema de Keyes, infectando-os com Streptococcus mutans e alimentado-os com uma dieta rica em açúcar. Os dentes foram examinados com laser em 488nm e observaram o pico da fluorescência ocorrendo em $540 \mathrm{~nm}$ e as cáries eram vistas como áreas escuras e o esmalte sadio aparecia como áreas claras possibilitando o diagnóstico precoce de cáries.

A dentina quando é excitada com 460 e 488nm observa-se uma diminuição na intensidade da fluorescência na dentina cariada. A dentina desmineralizada apresenta menor espalhamento e/ou mais forte absorção nesses comprimentos de onda (Van der Veen, Ten Bosch, 1995).

Quando o tecido é excitado com o comprimento de onda na região do verde a intensidade de fluorescência do tecido cariado é maior que a do tecido sadio. Os tecidos sadio e cariado excitados com $515 \mathrm{~nm}$ apresentam pico de fluorescência em 529nm (Van der Veen, Ten Bosch, 1996b).

Matsumoto et al. (1999) observaram as características estacionárias e dinâmicas da autofluorescência na dentina humana sobre exame da fluorescência em tempo de nanosegundo. Relataram que com o envelhecer, a intensidade da fluorescência aumenta enquanto que o tempo de decaimento diminui. Não houve nenhuma diferença na intensidade da fluorescência, tempo de decaimento ou perfil espectral entre tipos de dentes do mesmo individuo ou de individuos da mesma idade. A intensidade da fluorescência foi aumentada depois da aplicação de calor $\left(37^{\circ} \mathrm{C}\right.$ e $\left.50^{\circ} \mathrm{C}\right)$, mas permaneceu inalterado enquanto os espécimes foram mantidos em $4^{\circ} \mathrm{C}$.

Chaves (2001) irradiou três grupos de dentes constituído o grupo 1 por dentes hígidos, no grupo 2 os dentes foram submetidos a solução desmineralizadora de Ten Cate por 72 horas e no grupo 3 os dentes apresentavam lesões cariosas visíveis em superfície lisa. Os grupos foram irradiados com laser de 
argônio $(488 \mathrm{~nm}$ ) com $300 \mathrm{~mW}$ de potência. O autor observou que o esmalte sadio apresentava intensidade de fluorescência maior do que os dentes submetidos a solução desmineralizadora.

Hibst e Gall (1998) apresentaram um sistema de diagnóstico que excita o tecido dental com diodo em $655 \mathrm{~nm}$, contrariando os estudos até nesse momento que fazem uso em sua grande maioria a excitação no azul e no verde. Nesse trabalho eles afirmam que tecidos não cariados possui uma queda muito grande na intensidade da fluorescência quando excitado no espectro vermelho, enquanto o tecido cariado possui uma grande intensidade de fluorescência e demonstram que a penetração do laser no tecido para provocar fluorescência é até $1 \mathrm{~mm}$ no tecido.

Hibst e Paulus (1998) propuseram que o mecanismo fundamental de aumento da fluorescência na presença de bactérias é um resultado da integração de metabólitos bacterianos e desintegração de cristais. Em 1999, os autores observaram uma diminuição da fluorescência em $640 \mathrm{~nm}$ e $655 \mathrm{~nm}$, mas essa diminuição é muito mais pronunciada para tecidos sadios quando comparado com o esmalte ou dentina cariados (Hibst; Paulus, 1999).

Hibst e Paulus (1999) demonstraram que quando o tecido é excitado com o comprimento de onda vermelho apresenta as maiores razōes entre tecido cariado e tecido sadio e quando foi comparado dois comprimentos de onda vermelho, $640 \mathrm{~nm}$ e $655 \mathrm{~nm}$, o comprimento que demonstrou a maior a razão entre tecido cariado e sadio foi o de $655 \mathrm{~nm}$, apesar de ser pequena essa diferença em valores absolutos. Nesse trabalho apresentam o Diagnodent 8 (KaVo, Biberach, Alemanha), onde trabalham com espectroscopia de fluorescência com excitação na região do vermelho em $655 \mathrm{~nm}$ e determinam que a fluorescência é eficaz até espessuras de $1 \mathrm{~mm}$ no tecido com a intensidade da fluorescência decaindo exponencialmente com o aumento da espessura do tecido. Os autores observam que o tecido sadio apresenta baixa intensidade de fluorescência quando excitado nesse comprimento 
de onda ao contrário do tecido cariado que possui alta intensidade de fluorescência. Os autores determinam que o tecido quando excitado com $655 \mathrm{~nm}$ e $640 \mathrm{~nm}$ a razão da intensidade do tecido sadio e cariado em $736 \mathrm{~nm}$ é 7,3 e 6,9 , respectivamente. Através desse estudo é desenvolvido em colaboração com Kaltenbach e Voigt (KaVo, Biberach, Alemanha) o Diagnodent 8 .

O Diagnodent $($ tem mostrado ser um método de diagnóstico sensivel quanto ao valor quantitativo, de fácil utilização e com alta reprodutibilidade, sendo necessário aliar o aparelho ao método clínico, sendo possível sua utilização em superfícies lisas, bem como, na superfície oclusal e em cáries ocultas (Mello et al., 2001).

O Diagnodent $\mathbb{B}$ excita o tecido dental com laser de diodo vermelho em $655 \mathrm{~nm}$ com potência menor ou igual a $1 \mathrm{~mW}$. O aparelho possui duas pontas $A$ e $B$, sendo usada na superfície oclusal e lisa, respectivamente. É necessário que faça uma profilaxia no dente antes de realizar a leitura, pois placa bacteriana, alterações de cor e materiais de restauração podem alterar a leitura do aparelho. É possivel calibrar o aparelho através da cerâmica de calibração, tendo a possibilidade de calibrar no dente que será realizado a leitura da cárie. O sinal mostrado no visor, vai de 0 a 99, correlacionando o valor com o grau da lesão cariosa (KaVo).

Lizarelli et al. (2000) estudaram 22 dentes, in vitro, pré-molares e molares que pareciam ter lesões cariosas na sua superfície oclusal. Foi realizadas inspeção visual, exame com sonda exploradora, radiografia convencional, radiografia digital, Diagnodent $($ e avaliação histológica. Nesse estudo foi utilizada a tabela de Joshi, onde 0 - tecido sadio, 1-25 - desmineralização de esmalte, 25-45 - cárie de esmalte e acima de 45 - cárie em dentina. Os autores concluíram que o Diagnodent $囚$ foi superior aos métodos convencionais de diagnóstico, porém, deve ser utilizado apenas como método auxiliar de diagnóstico devido à presença de resultados falso-positivos. 
Não existe um consenso entre os autores em correlacionar o valor medido com o grau da doença, isso gerou diversas tabelas:

0-4 - Ausência de cárie, 4,01-10 - cárie em esmalte, 10,01-18 - cárie em dentina na metade externa e maior que 18 - cárie em dentina na metade interna (Lussi et al., 1999).

0-9 esmalte sadio ou cárie inicial de esmalte, 10-17 cárie em esmalte, 18-99 cárie em dentina (Attrill et al., 2001).

0-13 sem cárie ativa, 14-20 devem ser tomados cuidados preventivos, 21-29 devem ser tomados cuidados preventivos ou restauradores dependendo do risco do paciente e valores maiores de 30 devem ser tomadas medidas restauradoras (Lussi et al., 2001).

Tabela do fabricante: 0-5: sadio, 5-10 desmineralização do esmalte, 10-20 cárie de esmalte, acima de 20 cárie de dentina (Granville-Garcia et al., 2000; Zanin et al., 2000).

Essa diversidade de tabelas demonstra que o aparelho não deve ser utilizado como método de diagnóstico. Porém esses autores concordam que o Diagnodent $(8)$ foi superior aos métodos convencionais e apresentou boa reprodutibilidade de resultados.

Quando o profissional avaliar uma cárie com o Diagnodent@8 deve considerar em conjunto o escore fornecido pelo aparelho, a higienização e dieta do paciente, com isso, possibilitando o monitoramento dos processos cariosos e ajudando o profissional a avaliar a evolução ou paralisação da cárie, além de ter várias medidas da lesão ao longo do tempo.

Lussi et al. (1999) avaliaram a validade dos resultados do Diagnodent 8 , determinando valores para os vários estágios de cárie e a reprodutibilidade do aparelho em 105 dentes com a superfície oclusal intacta. Encontraram reprodução nas medidas do Diagnodent $($ e resultados válidos para 0 monitoramento 
longitudinal das cáries e possibilitou avaliar se as medidas preventivas que estão sendo realizadas estão sendo eficientes. Realizaram uma comparação do Diagnodent $($ com Electronic Caries Monitor $(E C M)$ e o Diagnodent $($ mostrou melhor reprodutibilidade.

Stookey et al. (1999) estudaram o uso do Diagnodent $($ na deteç̧ão precoce de cáries em 150 crianças. Nesse estudo utilizaram o método convencional (espelho e sonda), condutividade elétrica e métodos de fluorescência (QLF) e radiográfico. O resultado foi que no método convencional quando utilizou o explorador detectou mais cárie do que quando não o utilizou. Quando utilizou o QLF (Quantitative Light Fluorescence) obteve-se os melhores resultados no diagnóstico de cárie e ainda permitiu o monitoramento da lesão de forma a verificar se a lesão apresentou evolução ou regressão em esmalte.

O Diagnodent@ é superior ao método radiográfico em cáries oclusais demonstrando boa reprodutibilidade de resultados. A umidade do dente influencia a leitura dos resultados acusando medidas menores, porém é um método confiável para monitorar cáries (Shi et al., 2000).

A superfície do dente que demonstra maior dificuldade no diagnóstico de cárie e a maior incidência da doença é a superficie oclusal e o Diagnodent $\mathbb{B}^{\circ}$ mostrou-se eficiente no diagnóstico de cárie oclusal apesar dos diagnósticos falsopositivos, sendo útil como método complementar de diagnóstico (Duarte et al., 2000; Granville-Garcia et al., 2000; Pardi et al., 2000; Ferreira et al., 2001).

No monitoramento de cáries sob selantes o Diagnodent@ mostrou-se eficiente para detectar a lesão cariosa sob selante, sendo que houve uma diminuição nas medidas (Takamori et al., 2001).

Pigmentações no dente interferiram no diagnóstico de cárie com Diagnodent $\Theta$, aumentando o número de diagnósticos falso-positivos, não ocorrendo 
o mesmo quando se comparou com a espectroscopia de fluorescência (Ribeiro, 2001).

Para promover a fluorescência do tecido tem-se utilizado como fonte de excitação na maioria dos casos lasers. Ribeiro (2001) obteve resultados válidos quando substitui as fontes de lasers por LEDs com a vantagem de possuirem um custo muito inferior. Em seu trabalho observou-se que dentes mergulhados em diversas bebidas, que permitiam a incorporação de pigmentos, apresentavam alteração nos escores do Diagnodent $\Theta$ com registro de aumento de valores. 
III. EXPERIMENTO I

\section{III.1. DETERMINAÇÃO DA FIGURA DE MÉRITO A PARTIR DO ESPECTRO DE FLUORESCÊNCIA}

A fluorescência pode ser comparada como uma impressão digital de compostos químicos que possuem a propriedade de fluorescer quando excitados por determinados comprimentos de onda possibilitando a identificação desses compostos.

A fluorescência é utilizado na química e engenharia, com grande sucesso, para identificação de elementos químicos $e$ identificação de materiais. $A$ fluorescência possibilita, com precisão, qualificar e quantificar a presença de elementos capazes de fluorescer, ou seja, quando o elemento possui a capacidade de fluorescer é possível determinar sua presença e quantidade.

A Medicina tem aproveitado essa caracteristica da fluorescência em diferenciar substâncias e incorporou essa ferramenta no diagnóstico de tecidos sadios e patológicos com a vantagem de apresentar a possibilidade de ter respostas imediatas.

A Odontologia iniciou a incorporação da fluorescência como meio de diagnóstico da cárie a partir da década de 80 e no final da década de 90 houve o lançamento de um aparelho comercial para o diagnóstico de cárie por fluorescência, o Diagnodent $\circledast$. 
Quando se utiliza a fluorescência para o diagnóstico de cárie é possivel fazer o exame por dois métodos: fluorescência por imagem e fluorescência por análise espectral.

$\mathrm{Na}$ fluorescência por imagem faz-se a excitação do tecido e uma câmera acoplada faz a captação da imagem. Essa câmera possui um filtro que retira a luz de excitação, com isso, observa-se somente a fluorescência.

Na fluorescência por análise espectral faz-se a excitação do tecido com uma fonte de laser e o sistema capta a fluorescência em todo o seu espectro. Isso permite a quantificação dessa fluorescência em comprimento de onda por intensidade de fluorescência.

\section{III.2. OBJETIVOS}

Nosso trabalho tem o objetivo de analisar o espectro de fluorescência utilizando três comprimentos de onda: 442,532 e $632 \mathrm{~nm}$, excitando esmalte e dentina sadios e dentina cariada, com isso, determinando características da fluorescência dos tecidos sadios e cariado.

Além disso, o outro objetivo desse experimento é determinar formas de processar os espectros de fluorescência de modo que possamos diferenciar tecido sadio de tecido cariado. 


\section{III.3. MATERIAIS E MÉTODOS}

\section{III.3.1. DENTES}

Foram selecionados 40 dentes permanentes humanos de diferentes grupos dentais. Os dentes foram extraídos depois de indicação clínica e foram armazenados em soro fisiológico a temperatura ambiente até o momento do experimento.

Durante $\odot$ armazenamento do dente não foi adicionado nenhum produto para não alterar as características de fluorescência do tecido.

A única profilaxia feita nesses dentes foi a lavagem com soro fisiológico para não provocar incorporação de produtos de profilaxia no tecido dental cariado e alterar as características de fluorescência.

Foram investigadas superfícies na dentina da raiz (não cariada), esmalte (não cariado) e uma superfície dentinária visualmente cariada. Cada dente apresentava uma superficie de esmalte e dentina sadios e uma superficie cariada acometendo a dentina.

A porção radicular foi previamente preparada removendo o cemento de modo a não interferir na fluorescência da dentina. Em um exame visual todos os dentes selecionados exibiram uma cárie dentinária evidente, esmalte e dentina não cariados.

O critério de seleção desses dentes foi determinado de forma que houvesse uma superfície de esmalte sadia, uma de dentina não cariada localizada na raiz e uma superfície na coroa, onde houvesse uma cárie profunda que já tivesse atingido dentina. 
A superfície de dentina sadia foi escolhida na porção radicular do dente, sendo eliminado o cemento dessa região com broca diamantada em alta rotação refrigerado com água $e$ ar.

A superfície dentinária sadia foi escolhido na raiz, pois a fluorescência da dentina não altera com a região e profundidade que essa seja medida, podendo ser na porção radicular ou coronária (Matsumoto et al., 1999).

\section{III.3.2. SISTEMA DE FLUORESCÊNCIA ESPECTRAL}

A análise da espectroscopia foi realizada por um sistema de fluorescência espectral com partes fornecidas pela empresa russa CLUSTER (Cluster LTD e Mettem-Proizvodstvo LTD, Moscou - Rússia). Esse sistema é composto por três lasers para excitação do tecido, um explorador óptico, um monocromador e um computador.

A luz proveniente dos lasers é conduzida até o tecido através de uma fibra óptica. A fluorescência é captada pela fibra óptica e conduzida ao monocromador onde é analisado o comprimento de onda em função da intensidade da fluorescência. Ligado ao monocromador há um computador onde são armazenados os dados (figura 1).

Foi utilizado uma fibra óptica tipo $\mathrm{Y}$ com a fibra central conduzindo o laser de excitação e seis fibras dispostas concentricamente à fibra central com a função de captar a fluorescência. A fibra central possui um diâmetro de $110 \mu \mathrm{m}$ e as fibras periféricas $100 \mu \mathrm{m}$ de diâmetro. A fibra central é ligada ao laser para conduzi-lo até - tecido e as fibras periféricas conduzem a fluorescência do tecido até o monocromador. 


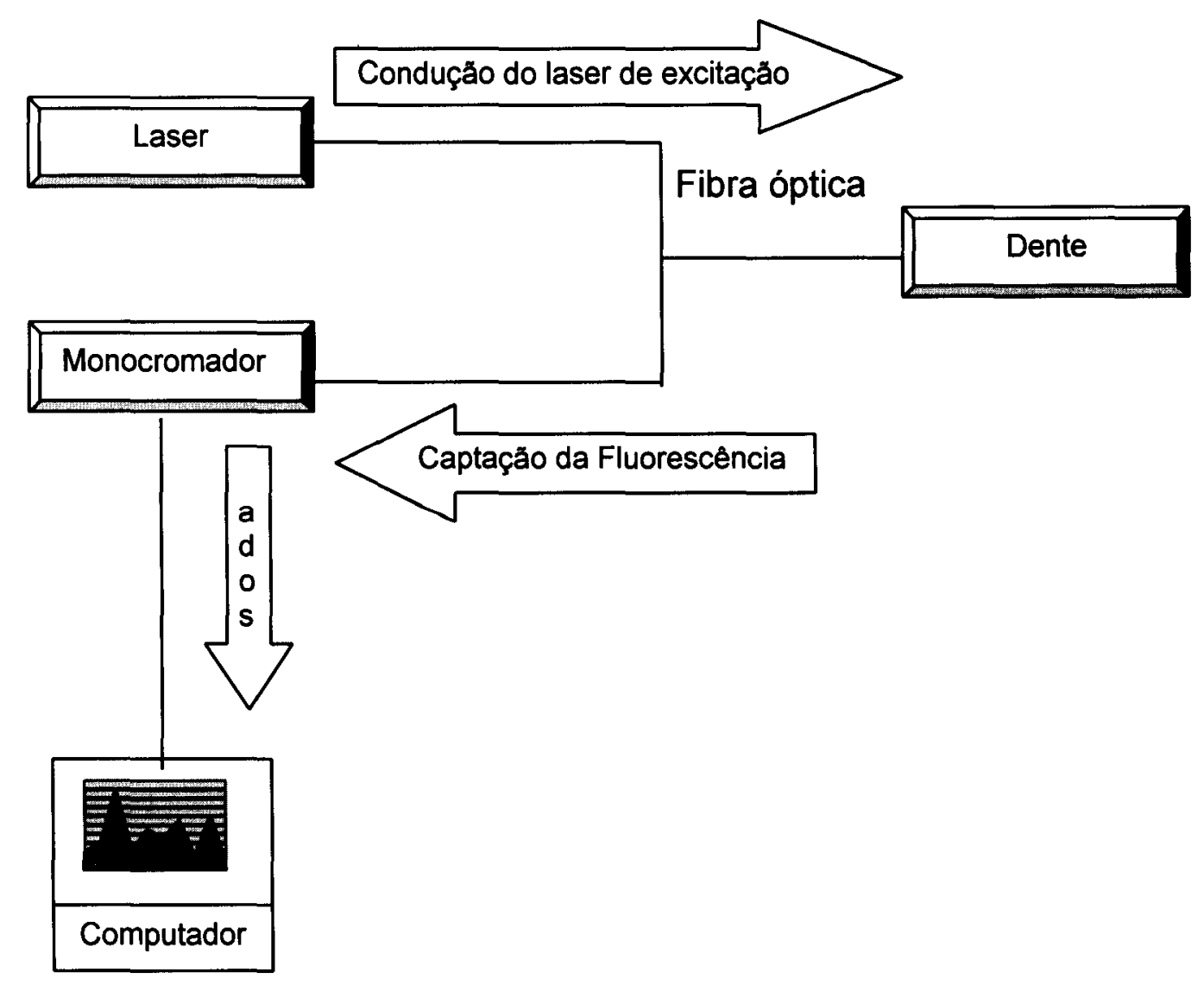

Figura 1 - Diagrama esquemático do sistema de fluorescência

Foram utilizados três diferentes comprimentos de onda para excitação das amostras, $442 \mathrm{~nm}$ de uma fonte de $\mathrm{HeCd}$ (figura 2), $532 \mathrm{~nm}$ gerado por uma fonte de Nd:YAG dobrado (figura 2) e 632nm fornecido por um laser de HeNe (figura 3), sendo as potências de $5 \mathrm{~mW}, 7 \mathrm{~mW}$ e $3 \mathrm{~mW}$, respectivamente.

A fluorescência e a luz de espalhamento foram avaliadas por um monocromador (figura 4) acoplado a um computador onde todo o espectro contendo espalhamento no mesmo comprimento de onda $(\lambda)$ da excitação e região de fluorescência foi registrado. O computador, também, apresenta um software que permite o processamento e armazenamento dos dados (LightView-Med). 


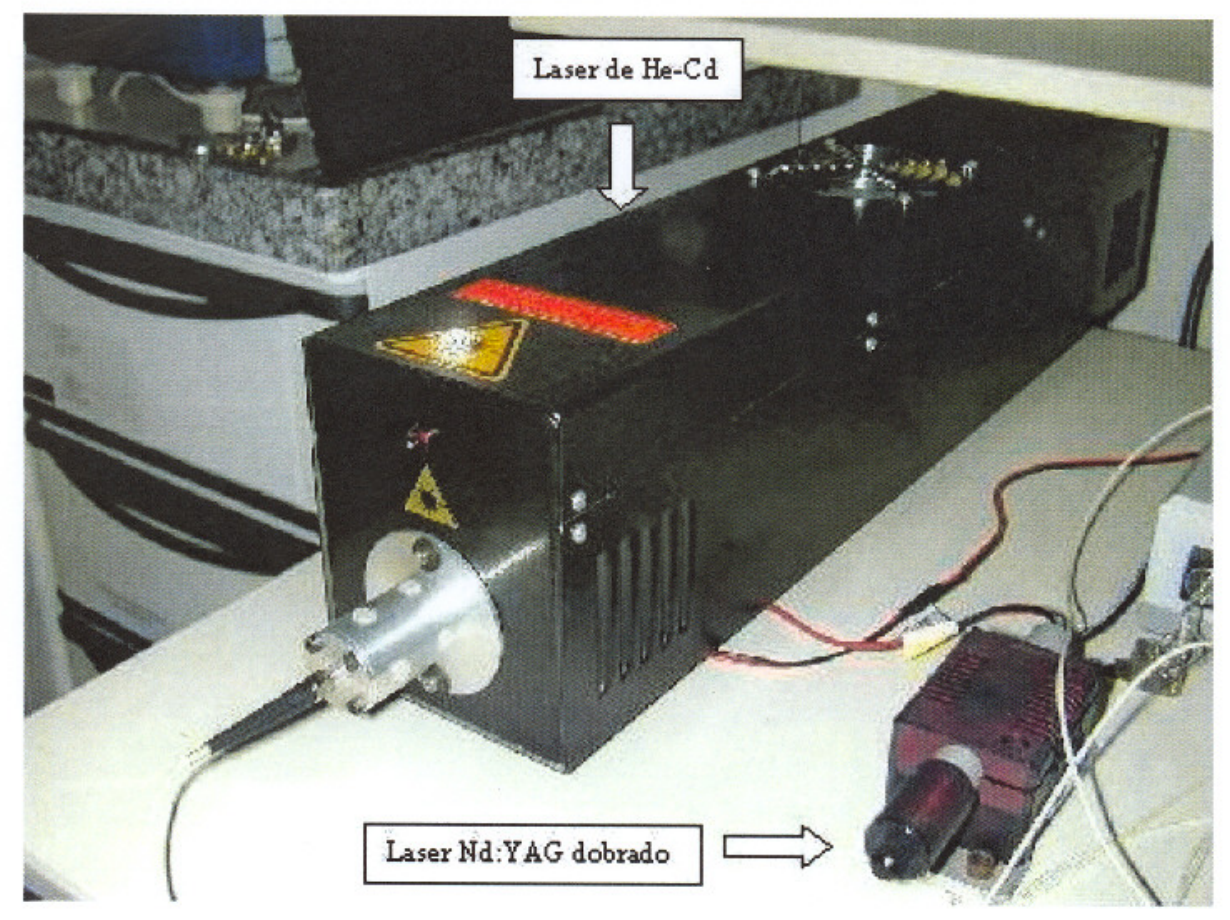

Figura 2 - Laser de He-Cd (esquerda) e Nd:YAG dobrado (direita)

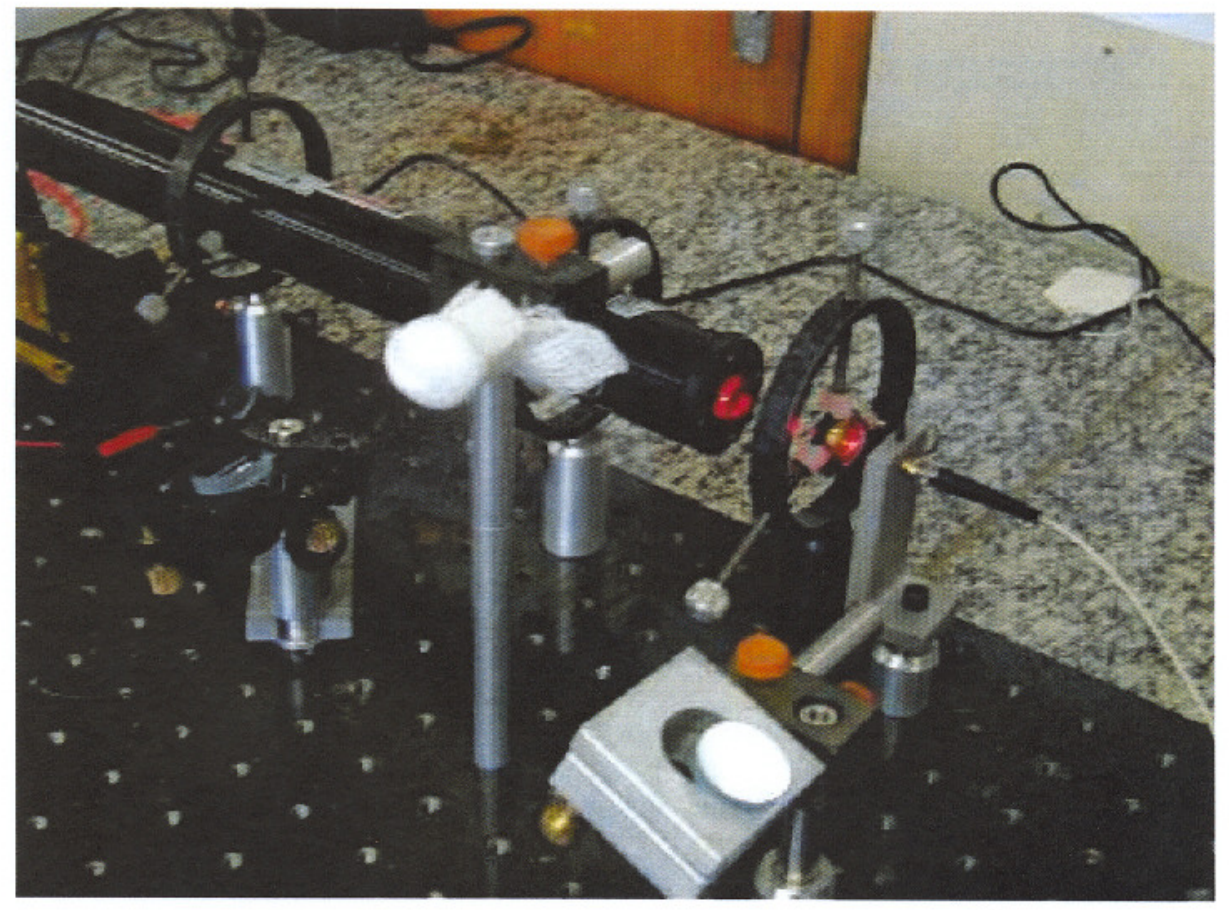

Figura 3 - Laser de $\mathrm{HeNe}$ 


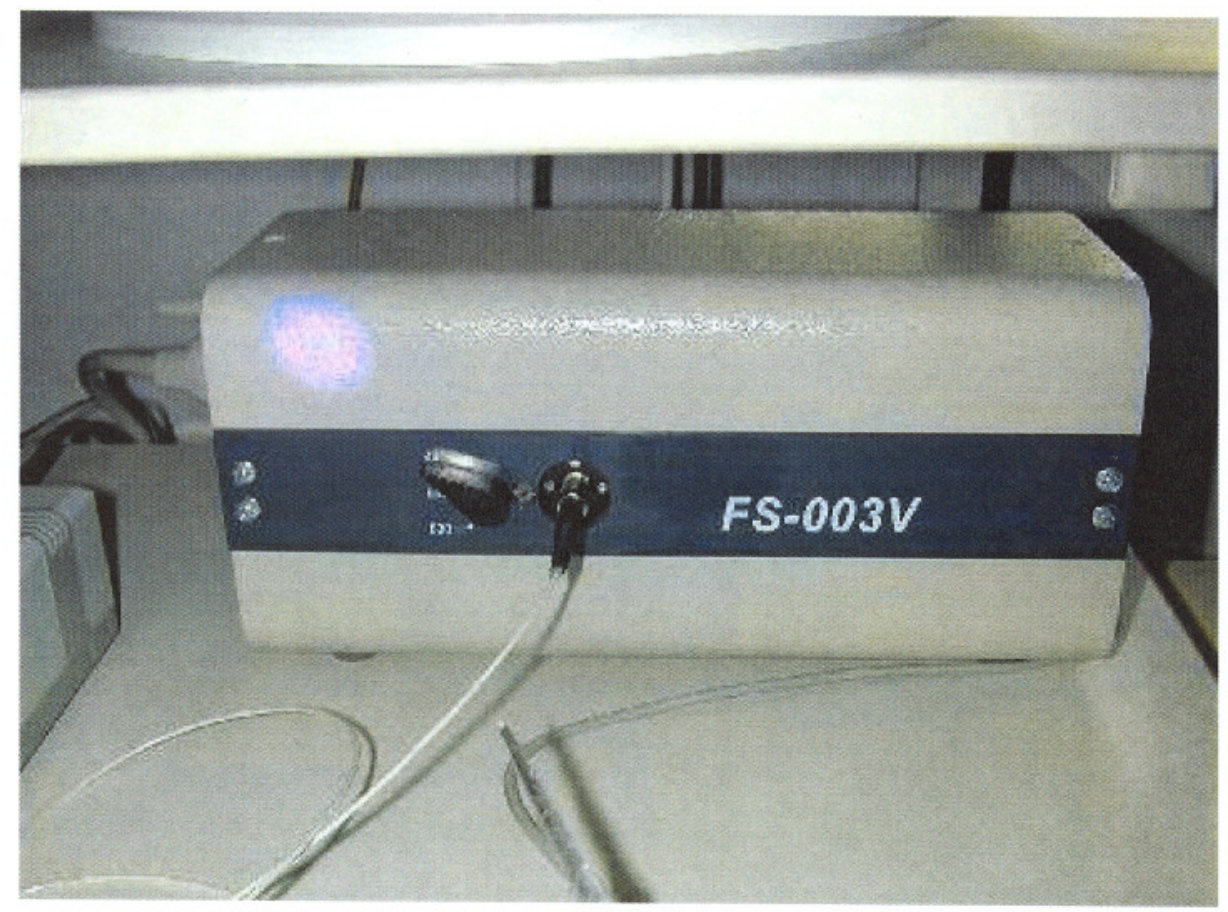

Figura 4 - Monocromador

\section{III.3.3. AQUISIÇÃO DOS DADOS}

Cada dente foi analisado em 3 diferentes regiões: dentina cariada, dentina e esmalte sadios. O posicionamento da fibra foi padronizado de forma que ficasse posicionada em contato e perpendicularmente ao tecido analisado para diminuir as perdas por reflexão (figura 5).

As medições ópticas foram armazenadas em um total de 120 espectros para cada tecido e comprimento de onda analisado. As medidas foram sempre realizadas em três pontos distintos de cada tecido.

Os resultados obtidos foram processados de duas formas para determinar uma figura de mérito. A primeira forma de processamento da figura foi feita pelo 
pico da fluorescência e a segunda forma de análise foi levando em consideração a área da fluorescência.

A aquisição e processamento dos espectros ocorrem com a excitação dos tecidos pelas fontes de lasers que são conduzidos por uma fibra em Y. Essa fibra capta cada comprimento de onda e sua intensidade esses espectros são processados e gerando uma Figura de Mérito (figura 6).

Esse protocolo de pesquisa recebeu a aprovação do Comitê de Ética da Universidade Estadual Paulista (Araraquara - São Paulo - Brasil) (figura 7).

O sistema de análise da fluorescência capta a fluorescência gerada pelo tecido e o comprimento de onda de excitação que gerou a fluorescência. Esse espectro é gerado em tempo real na tela do computador.

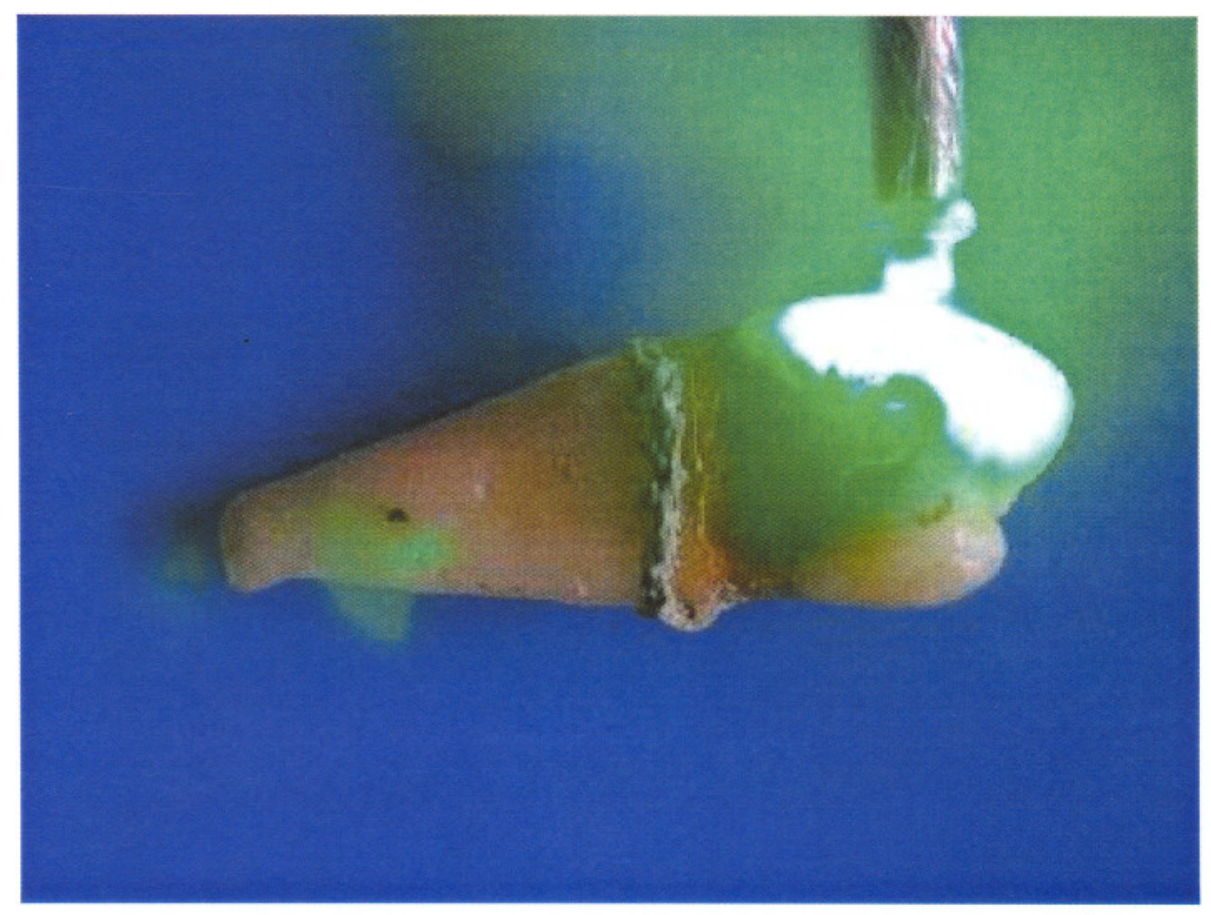

Figura 5 - Leitura de autofluorescência do esmalte sadio excitado com $532 \mathrm{~nm}$. 


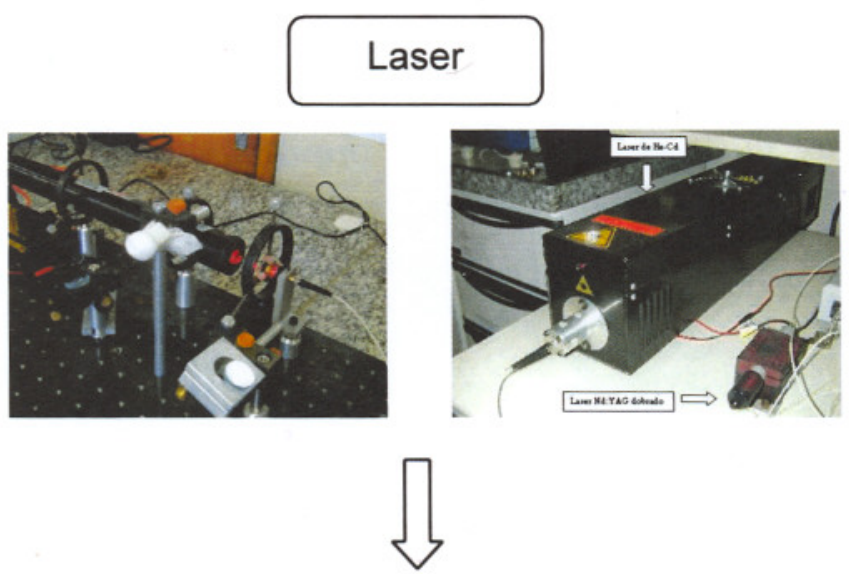

Fibra $Y$

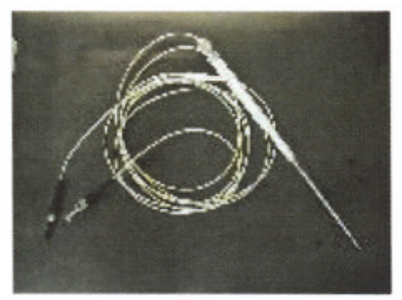

$\sqrt{5}$

Aquisição de cada comprimento de onda

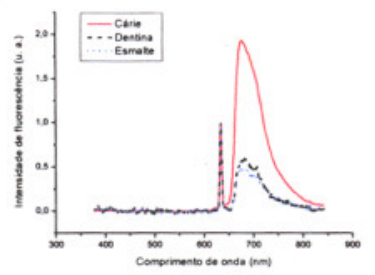

$\sqrt{ }$

Processamento do espectro

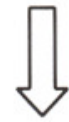

Figura de Mérito

Figura 6 - Esquema da aquisição e processamento do espectro 
O gráfico gerado pelo computador é feito em intensidade pelo comprimento de onda. Na figura 8 pode-se observar um gráfico típico da intensidade de fluorescência como função do comprimento de onda gerado pelo laser de $\mathrm{He}-\mathrm{Ne}$, He-Cd (figura 9) e Nd:YAG dobrado (figura 10) com comprimento de onda de $632 \mathrm{~nm}, 442 \mathrm{~nm}$ e $532 \mathrm{~nm}$, respectivamente.

Os espectros foram normalizados pelo primeiro pico que pode ser observado nas figuras 8,9 e 10, sendo esse pico o espalhamento elástico. Ele possui o mesmo comprimento de onda de excitação. Esse pico é decorrente do laser de excitação, podendo ver na figura 8 que esse pico está posicionado no gráfico em 632nm, na figura $9 \mathrm{em} 442 \mathrm{~nm}$ e na figura $10 \mathrm{em} 532 \mathrm{~nm}$. O segundo pico observado nos gráficos 8,9 e 10 é a fluorescência captada dos tecidos.

Existe um filtro no monocromador para diminuir a intensidade do laser de excitação em 1000 vezes para que não ocorra a inibição da fluorescência que é muitas vezes menos intensa que o laser de excitação. 


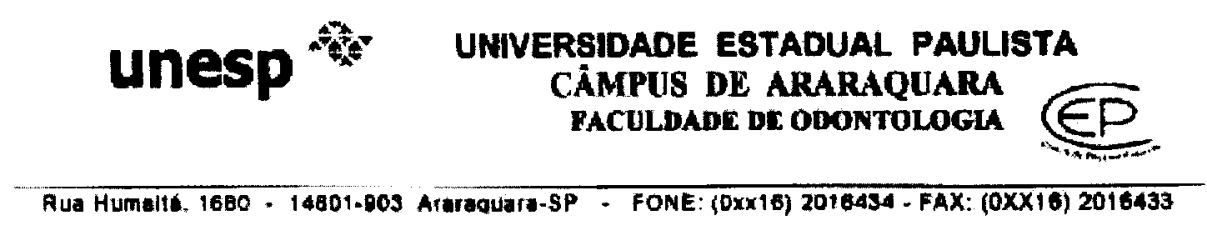

Araraquara, 15 de Março de 2002

Oficio CEP-FU/CAt. m" $048 / 2002$

Sernhor Pesquisador:

O Comité de Ética en Pesquisa da Faculdadr de Odontologin, reunido em sessđạ de 14.03.2002, após apreciar a avaliação final do Projeto dé sua responsabilidade intitulado "Diagndstico of colrie por espectromerria de fluaresctenciar, considerou-o APROVADO, derendo o relatitio ser aprescntado em Marb̧o/2003.

Atenciosametste

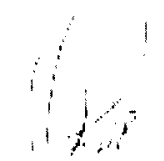

Prof Dr MIRLAN APARECIDA ONOFRE

Vice-Coortenador do Comitê de Etica em Pesquisa da Faculdade de Odontologia

Ilmo. Sr.

c. D. AUGUSTO cÉSAR RIBEIRO FIGUEIREDO

l'esquisador Responsáre!

MACSires

Figura 7 - Aprovação do Comitê de Ética em Pesquisa 


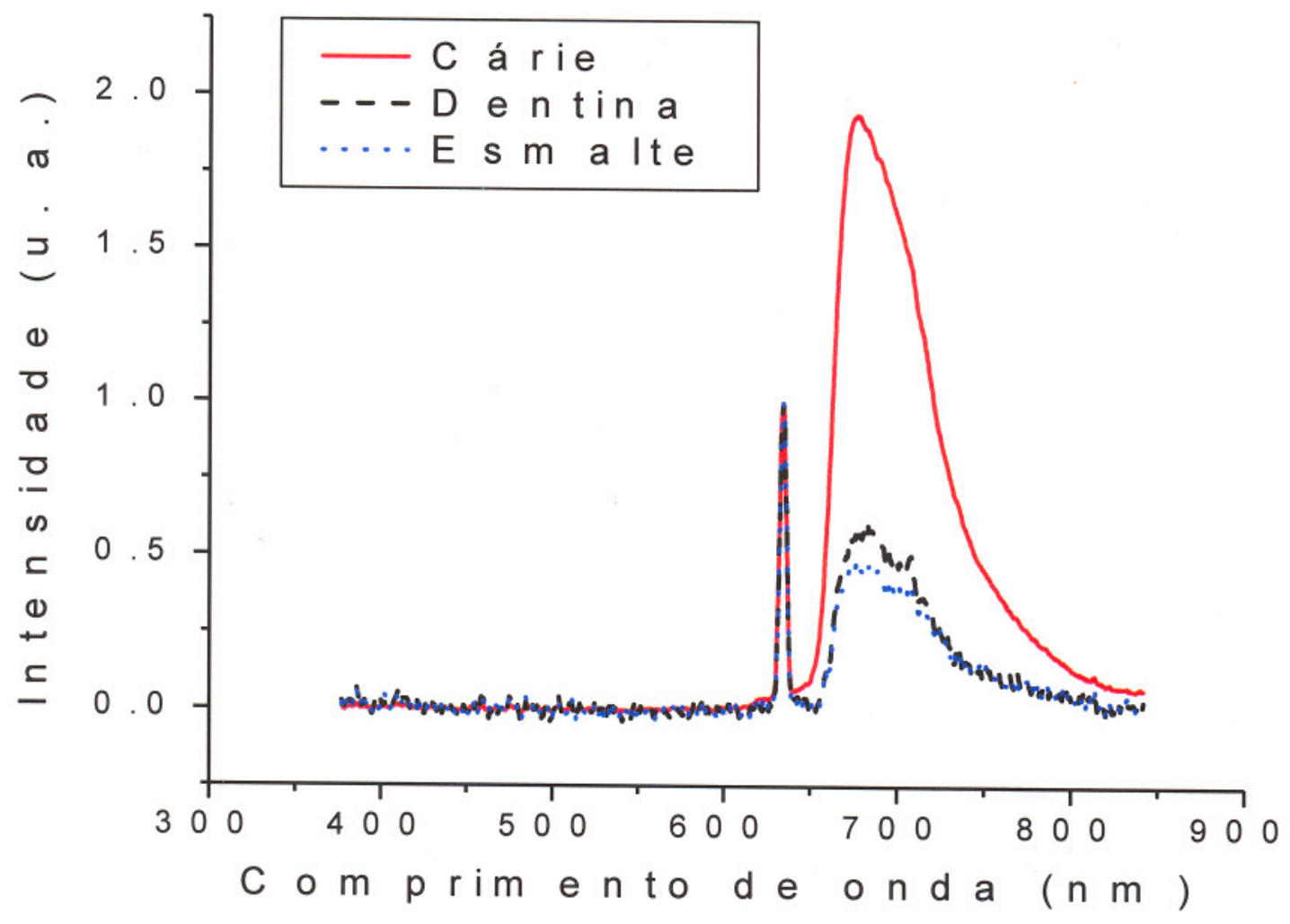

Figura 8 - Espectros de fluorescência para excitação com $632 \mathrm{~nm}$. O primeiro pico (esquerda) é o pico elástico cuja energia corresponde ao comprimento de onda de excitação (pico elástico) e a segunda região (direita) é a fluorescência (região inelástica). 


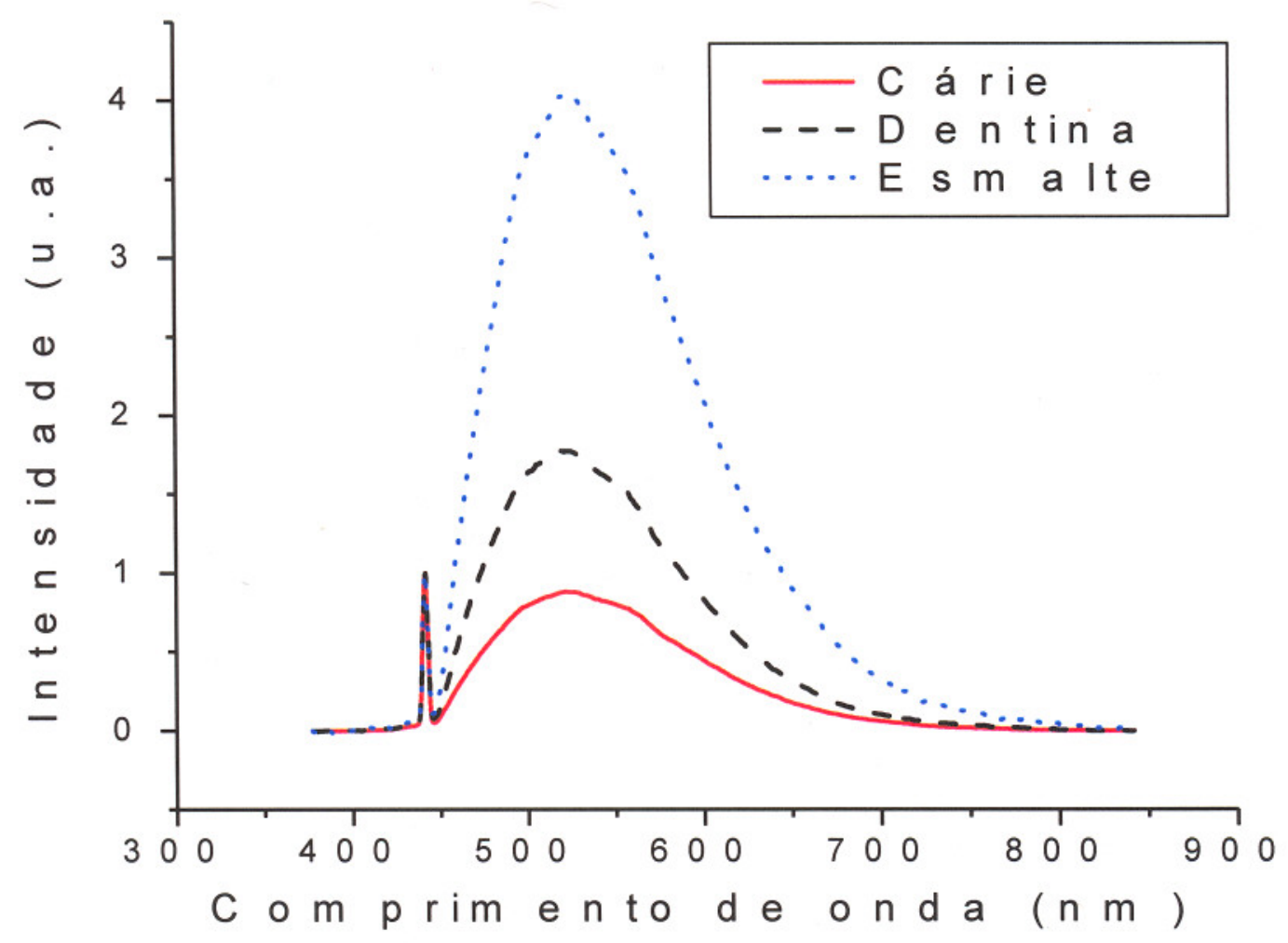

Figura 9 - Espectros de fluorescência para excitação com $442 \mathrm{~nm}$. O primeiro pico (esquerda) é o pico elástico cuja energia corresponde ao comprimento de onda de excitação (pico elástico) e a segunda região (direita) é a fluorescência (região inelástica). 


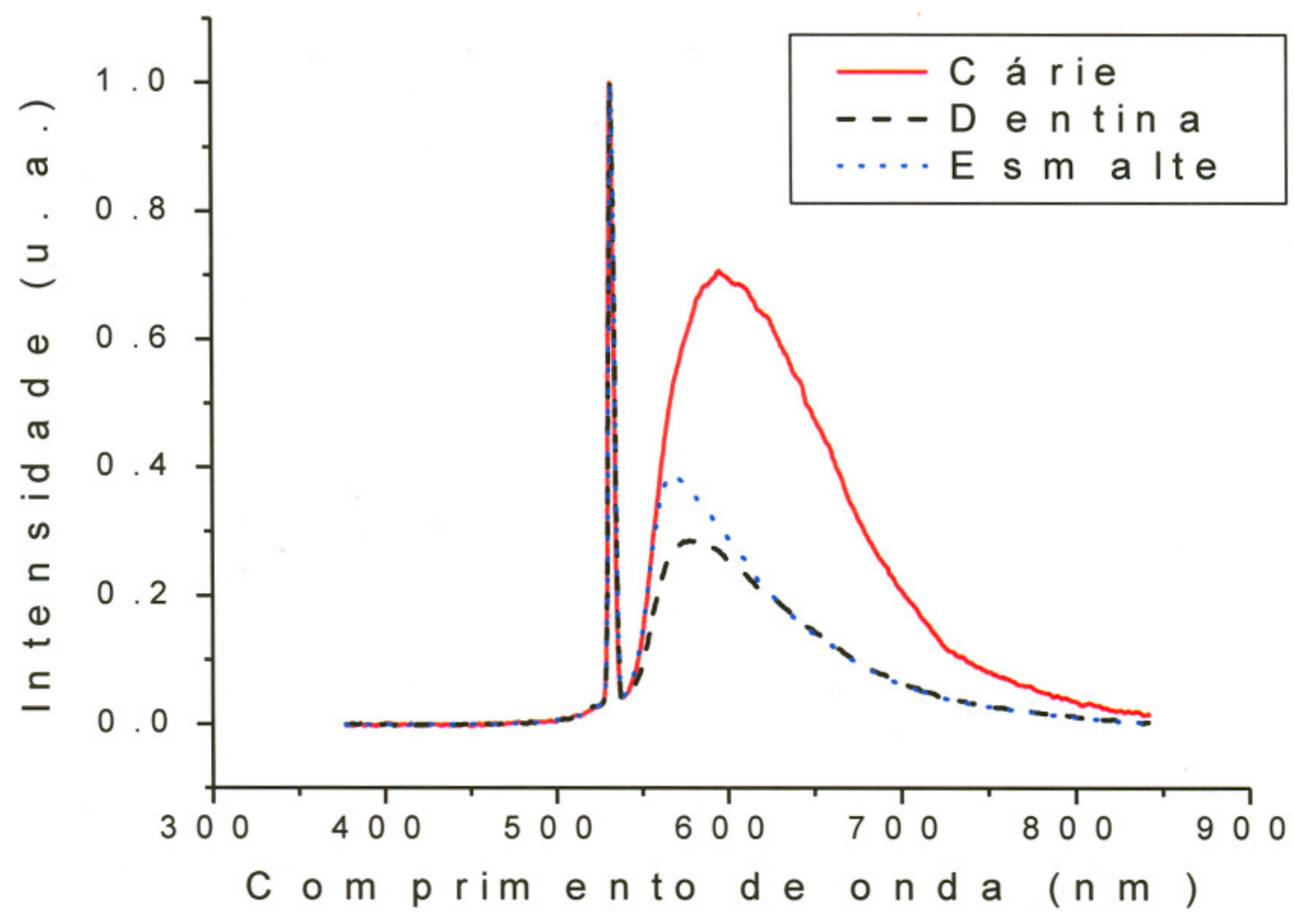

Figura 10 - Espectros de fluorescência para excitação com $532 \mathrm{~nm}$. O primeiro pico (esquerda) é o pico elástico cuja energia corresponde ao comprimento de onda de excitação (pico elástico) e a segunda região (direita) é a fluorescência (região inelástica).

\section{III.3.4. PROCESSAMENTO DOS DADOS}

A característica e condição superficial de cada tecido investigada promove diferenças na luz absorvida, especialmente quando a intensidade do pico elástico é considerada. 
Para produzir a fluorescência é necessário que os compostos a serem excitados na cárie estejam no primeiro milímetro, pois quando o tecido é excitado para emissão da fluorescência somente o primeiro milímetro de tecido é capaz de ser excitado para gerar fluorescência (Hibst; Gall, 1998).

De modo a permitir uma melhor comparação entre as amostras, todos os espectros foram inicialmente normalizados pelo pico elástico, isso permite remover variações causadas por diferenças no posicionamento da sonda no tecido.

Uma vez realizada a normalização, foi constituído uma Figura de Mérito (FM). No primeiro processamento da fluorescência foi determinado a FM1 a partir da razão da intensidade do pico elástico pelo pico inelástico. Esse tipo de análise consiste na correlação de dois pontos distintos do espectro.

$$
F M 1=\underset{\text { pico inelástico }}{\text { pico elástico }}
$$

No processamento dos espectros da fluorescência foi também analisada a razão da área total da fluorescência pela área total do espalhamento elástico, com isso, determinando a segunda Figura de Mérito que foi denominada FM2. A seguir é mostrada a fórmula para determinar a FM2:

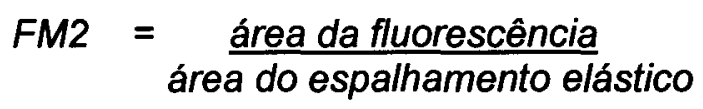

Foi realizada uma terceira análise dos espectros que consiste na razão da área da fluorescência pela área do espalhamento elástico, porém não foi utilizada toda área da fluorescência, mas somente os comprimentos de ondas finais. Isso gerou a terceira Figura de Mérito denominada de FM3, onde foi utilizado a mesma fórmula usada para calcular FM2. 
Para calcular as Figuras de Mérito 2 e 3 a área do espalhamento elástico foi calculada fazendo a integral da área do espalhamento elástico, quando o tecido foi excitado com $442 \mathrm{~nm}$ utilizamos para o cálculo da integral o intervalo de $432 \mathrm{~nm}$ à $446 \mathrm{~nm}$, quando excitado com $532 \mathrm{~nm}$ para o cálculo da área utilizamos o intervalo de $522 \mathrm{~nm}$ a $542 \mathrm{~nm}$ e para $632 \mathrm{~nm}$ utilizamos o intervalo de $622 \mathrm{~nm}$ a $642 \mathrm{~nm}$ para o cálculo da área.

Para o cálculo da área da fluorescência para determinar a Figura de Mérito 2 foi realizada a integral das áreas. Quando utilizamos a excitação com $442 \mathrm{~nm}$ para o cálculo da área realizamos a integral no intervalo de $447 \mathrm{~nm}$ a $800 \mathrm{~nm}$, com a excitação em $532 \mathrm{~nm}$ utlizamos o intervalo de $550 \mathrm{~nm}$ a $800 \mathrm{~nm}$ e para excitação com $632 \mathrm{~nm}$ o intervalo utilizado foi de 650 a $840 \mathrm{~nm}$.

No cálculo da Figura de Mérito 3 não utilizamos toda área da fluorescência, pois observamos que quando o tecido era excitado no comprimento de onda de $632 \mathrm{~nm}$ o tecido sadio apresentava pouca intensidade de fluorescência, ao contrário do tecido cariado que apresentava fluorescência. Quando o tecido foi excitado com $442 \mathrm{~nm}, 532 \mathrm{~nm}$ e $632 \mathrm{~nm}$ para o cálculo da área realizamos a integral nos intervalos de 700 a $840 \mathrm{~nm}$. 


\section{III.4. RESULTADOS E DISCUSSÃO}

\section{III.4.1. FIGURA DE MÉRITO 1 (FM1)}

A Figura de Mérito é um valor numérico que quantifica o processamento da fluorescência para poder fazer comparações entre os tipos de processamento da fluorescência e entre os comprimentos de onda.

Com o resultado numérico obtido do processamento da fluorescência determinamos a Figura de Mérito. Avaliamos primeiramente o pico do espectro da fluorescência e em seguida processamos a área da fluorescência, sendo o processamento da fluorescência sempre relacionado com o espalhamento elástico.

A primeira Figura de Mérito obtida foi a partir do processamento do pico da fluorescência e foi denominada de Figura de Mérito 1 (FM1).

Um típico espectro de fluorescência obtido da investigação das superfícies de um mesmo dente pode ser observado nas figuras 8,9 e 10 , onde são registrados os espectros para os três diferentes tipos de tecidos analisados. $\AA$ esquerda, nestes espectros, pode-se observar um estreito pico centrado no comprimento de onda de excitação. Este é a parte da luz incidente que não teve modificação do comprimento de onda, sendo denominada de "pico elástico".

O espectro de emissão corresponde a um conjunto de comprimentos de onda denominado de autofluorescência ou pico inelástico. Esse pico é obtido do espectro de autofluorescência na região de máxima intensidade emitida.

Como pode ser observado no espectro, depois da normalização, a excitação com $442 \mathrm{~nm}$ produz menor pico de fluorescência quando a cárie está presente, 
enquanto a cárie foi excitada com $532 \mathrm{~nm}$ e $632 \mathrm{~nm}$ produziu a maior intensidade de fluorescência.

Não deve ser extraída somente essa figura de mérito de espectro, porque ela envolve somente a análise de duas regiões específicas do espectro. Isso é similar ao procedimento usado pelo dispositivo comercial Diagnodent $\circledast$ produzido pela KaVo (Biberach, Alemanha).

Utilizando os três comprimentos de onda foi obtido a FM1 para esmalte, dentina sem cárie e dentina cariada para todas as amostras analisadas. Nessa análise foi utilizado Box Chart. Essa análise representa a distribuição dos valores da Figura de Mérito, onde as caixas representam o intervalo que contém $50 \%$ dos valores que ocorreram no teste, do $x$ até a caixa há uma distribuição de $25 \%$ dos valores, do $x$ até a primeira barra dentro da distribuição dos $25 \%$ dos valores temos $1 \%$ dos valores nesse intervalo e o ponto dentro caixas representa o valor médio das Figuras de Mérito (figuras 11, 12 e 13).

Com excitação em 442nm, observamos que o pico de fluorescência ocorre ao redor de $532 \mathrm{~nm}$ no esmalte e dentina cariada e sadia. No esmalte foi observada uma maior intensidade de fluorescência. Na dentina com ausência de cárie observou-se uma média intensidade de fluorescência e para cárie foi observado uma menor intensidade de fluorescência. Nessa energia de excitação a análise aqui proposta mostra que FM maior que 0,8 indica presença de dentina cariada. Por outro lado FM menor ou igual 0,6 indica ausência de cárie. $O$ esmalte com ausência de cárie mostrou uma FM menor que 0,4. Essa diferença entre cárie e ausência de cárie é boa suficiente para permitir uma distinção dos tecidos quando a excitação com $442 \mathrm{~nm}$ é utilizado.

Indo da excitação azul $(442 \mathrm{~nm})$ para excitação vermelha com $632 \mathrm{~nm}$ a dependência da FM da dentina cariada para a dentina sadia mostra propriedades opostas. 
Para excitação com $632 \mathrm{~nm}$, observamos que o pico da fluorescência ocorre ao redor de $680 \mathrm{~nm}$ nos tecidos dentais investigados. Nessa situação, a dentina cariada apresenta a maior intensidade de fluorescência, a dentina não cariada possui intensidade intermediária e o esmalte sadio a menor intensidade. Nesse caso FM1 menor que 1 indica alta probabilidade da presença de dentina cariada. Por outro lado, a FM maior que 1 indica ausência de cárie, com alta probabilidade.

Enquanto que para excitação com 442nm a mudança na FM1 de dentina cariada para dentina não cariada é somente $30 \%$, para excitação com $632 \mathrm{~nm}$ o contraste entre dentina cariada e dentina sadia é quase que um fator de 4.

Os resultados mostram que a detecção de cárie com $632 \mathrm{~nm}$ apresenta maior probabilidade de sucesso que com excitação com $442 \mathrm{~nm}$ considerando o tipo de análise realizada.

Para excitação com 532nm, observou-se o pico de fluorescência ocorrer ao redor de 570nm no esmalte e dentina cariada e sadia. Na cárie observou-se maior intensidade de fluorescência, no esmalte média intensidade e na dentina sadia a menor intensidade de fluorescência. A variação da FM1 para dentina é relativamente suficiente para o diagnóstico da cárie.

O fato de o esmalte apresentar a FM1 entre dentina cariada e dentina sadia pode criar uma complicação técnica para o uso dessa excitação para identificar o tecido cariado. 


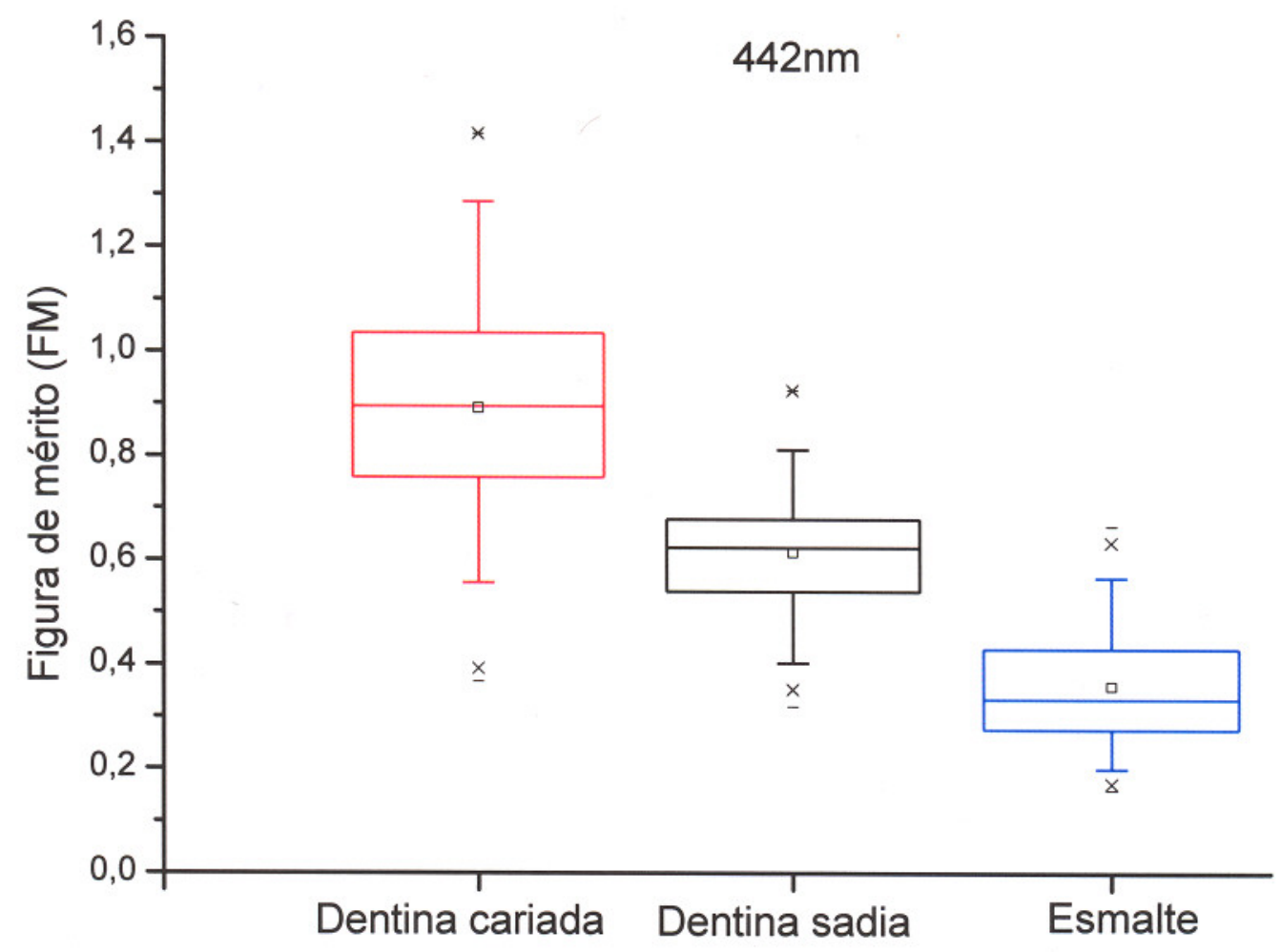

Figura 11 - Distribuição da razão do pico elástico pelo pico inelástico (FM1) para o esmalte, dentina sem cárie e dentina cariada quando excitado com $442 \mathrm{~nm}$. 


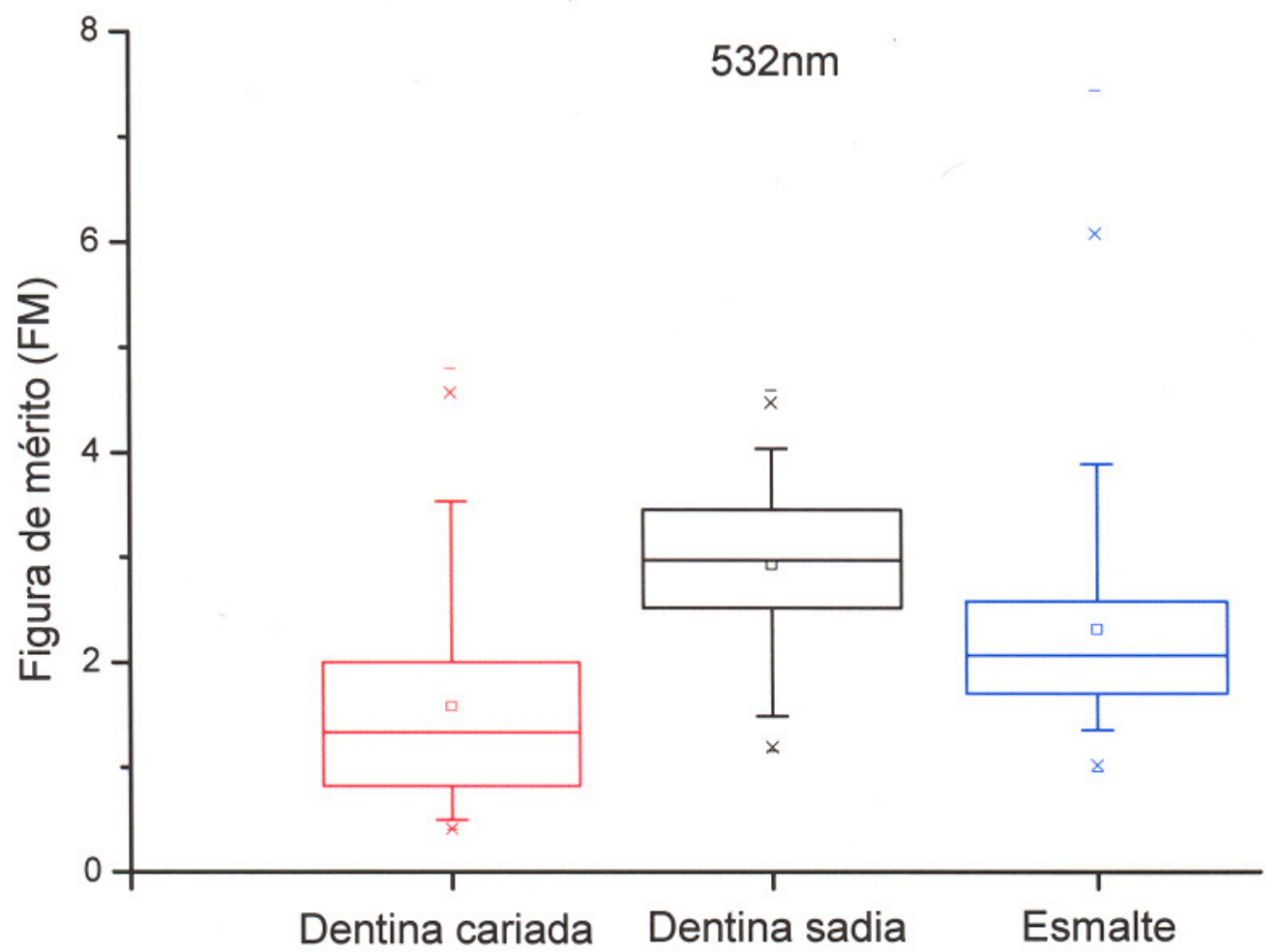

Figura 12 - Distribuição da razão do pičo elástico pelo pico inelástico (FM1) para o esmalte, dentina sem cárie e dentina cariada quando excitado com $532 \mathrm{~nm}$. 


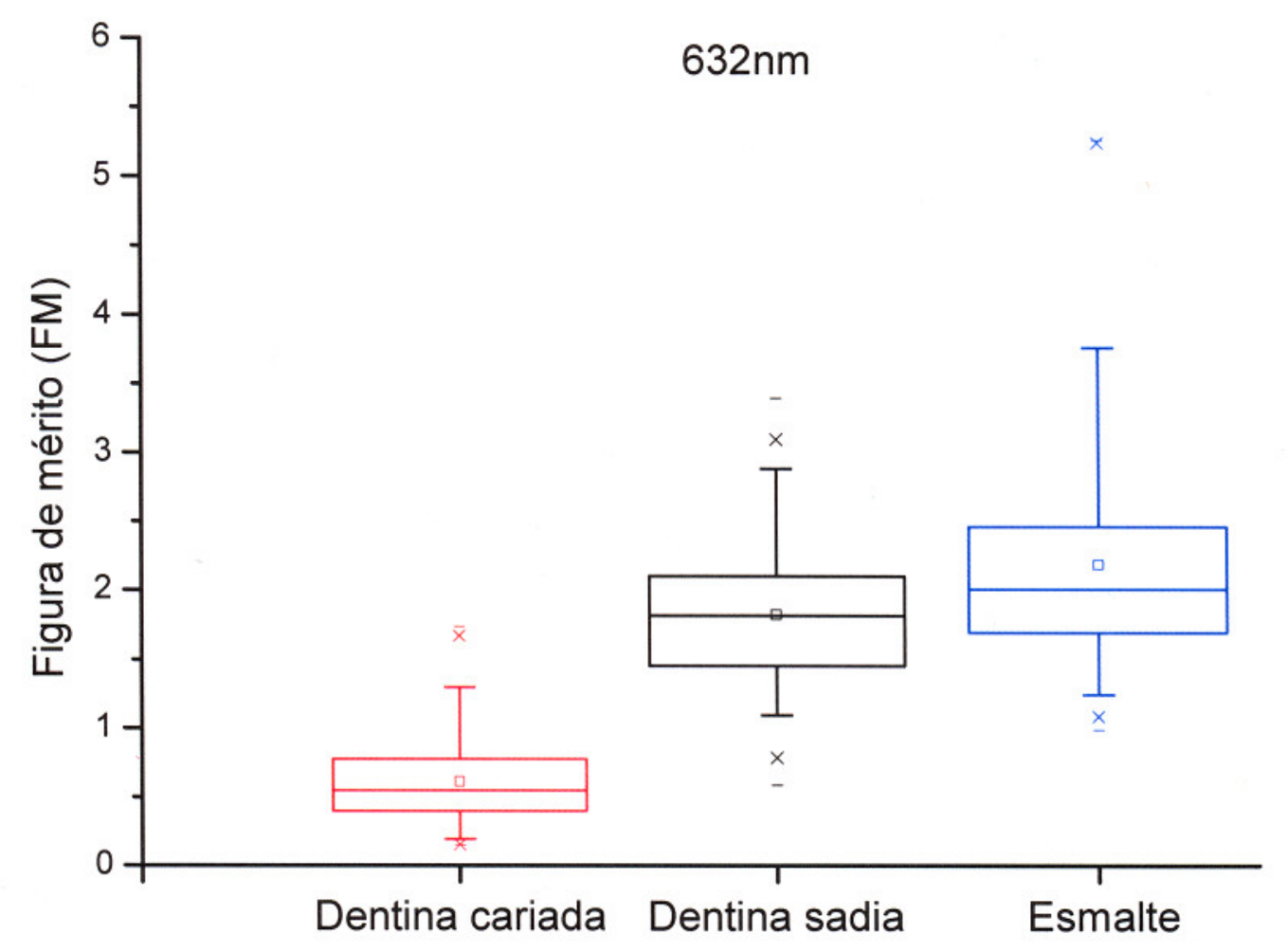

Figura 13 - Distribuição da razão do pico elástico pelo pico inelástico (FM1) para o esmalte, dentina sem cárie e dentina cariada quando excitado com $632 \mathrm{~nm}$. 
Na tabela I podemos observar um resumo das características geradas através da análise da FM1.

\begin{tabular}{|c|c|c|c|c|}
\hline$\lambda$ de excitação & Esmalte (FM1) & $\begin{array}{c}\text { Dentina sadia } \\
\text { (FM1) }\end{array}$ & $\begin{array}{c}\text { Dentina } \\
\text { cariada (FM1) }\end{array}$ & $\begin{array}{c}\text { Pico de } \\
\text { fluorescência }\end{array}$ \\
\hline $442 \mathrm{~nm}$ & $<0,4$ & $<0,6$ & $>0,8$ & $532 \mathrm{~nm}$ \\
\hline $532 \mathrm{~nm}$ & $>2$ & $>2$ & $<2$ & $570 \mathrm{~nm}$ \\
\hline $632 \mathrm{~nm}$ & $>1$ & $>1$ & $<1$ & $680 \mathrm{~nm}$ \\
\hline
\end{tabular}

Tabela I - Resumo das características dos dados gerados por FM1.

Na tentativa de determinar um $\dot{\lambda}$ mais eficiente para o diagnóstico de cárie, segundo a análise adotada, foi estabelecido um fator contraste. O fator contrste avalia a capacidade do comprimento de onda em diferenciar tecido sadio de tecido cariado. Para avaliar o contraste como uma função do comprimento de onda de excitação na detecção da cárie definimos:

$$
\text { Contraste }=\frac{(F M) \text { tecido cariado }-(F M) \text { tecido sadio }}{(F M) \text { tecido sadio }}
$$

Os valores de FM utilizados nessa fórmula é o ponto médio da Figura de Mérito para cada tecido.

Os valores do contraste representam a capacidade de identificar a cárie com fluorescência e a FM aqui definida (figuras 11, 12 e 13). 
O gráfico do contraste em função do comprimento de onda de excitação é mostrado na figura 14 quando a dentina cariada é comparada à dentina sadia e a dentina cariada é comparada ao esmalte.

Observamos que os altos valores do contraste são obtidos nos extremos do espectro de excitação. As duas excitações em $442 \mathrm{~nm}$ e $632 \mathrm{~nm}$ devem ser, preferencialmente, usadas devido ao bom contraste obtido. Por outro lado, a excitação próxima de $500 \mathrm{~nm}$ não produz contraste suficiente, tornando praticamente impossível a deteç̧ão da cárie na dentina para excitação próximo a esses valores. Resultados similares foram obtidos quando o esmalte foi comparado com a dentina cariada.

Verificamos a presença de valores negativos para o contraste nesse gráfico. Esses valores negativos para o contraste quer dizer que o valor médio da Figura de Mérito do tecido sadio é maior que valor médio da Figura de Mérito do tecido cariado.

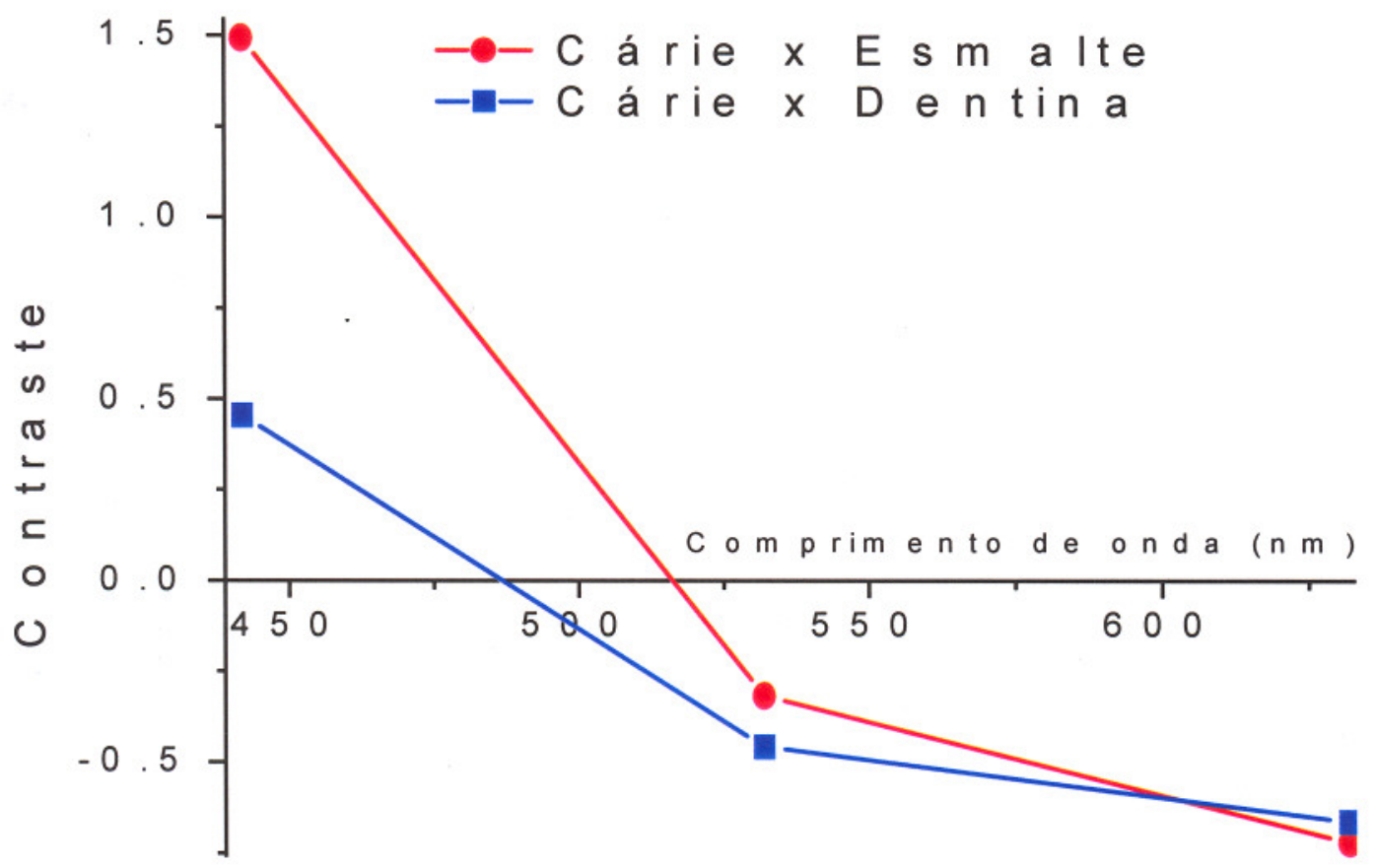

Figura 14 - Contraste para FM1 
O resultado apresentado na figura 14 é importante no sentido de permitir identificar regiões de excitação favoráveis para o diagnóstico da cárie. Se extrapolarmos para comprimentos de onda perto de $655 \mathrm{~nm}$, mostrado nesse gráfico, na condição do Diagnodent $\circledast$, há um bom contraste para o diagnóstico da cárie no comprimento de onda em que o Diagnodent $®$ trabalha.

\section{III.5. CONCLUSÃO}

\section{III.5.1. FM1}

Nessa Figura de Mérito (FM1) processamos o pico da fluorescência, nessa análise avaliamos a razão do pico elástico pelo pico inelástico. Essa forma de processar a fluorescência para diferenciar a cárie do tecido (esmalte e dentina) sadio mostrou ser sensível para o diagnóstico nos comprimentos de onda utilizados nesse experimento de $442 \mathrm{~nm}, 532 \mathrm{~nm}$ e $632 \mathrm{~nm}$.

O comprimento de onda de $442 \mathrm{~nm}$ mostrou ser importante no contraste do esmalte, dentina sadia e dentina cariada, enquanto que $532 \mathrm{~nm}$ mostrou menor sensibilidade para diagnosticar cáries avançadas e $632 \mathrm{~nm}$ apresentou sensibilidade para diagnosticar cárie, mas o contraste não difere os tecidos dentina e esmalte sadios.

O comprimento de onda de $532 \mathrm{~nm}$ é mais próximo do contraste zero que $632 \mathrm{~nm}$ e $442 \mathrm{~nm}$, esses dois comprimentos de onda extremos do espectro 
considerado, mostraram ser mais especificos para detecção da dentina cariada quando o método de observação dos dois pontos é utilizado.

\section{III.6. RESULTADOS E DISCUSSÃO}

\section{III.6.1. FIGURAS DE MÉRITO 2 e 3 (FM2 e FM3)}

Sistemas ópticos vêm demonstrando bons resultados no diagnóstico de cáries com índice de sucessos superiores aos métodos convencionais e a fluorescência vem obtendo grande destaque devido a sua capacidade de identificar compostos químicos.

Nessa parte do Experimento I processamos a área da fluorescência para isso produzimos as Figuras de Mérito 2 e 3 (FM2 e FM3). Na FM2 avaliamos a área total da fluorescência, enquanto na FM3 processamos apenas uma parte da área da fluorescência.

Nas tabelas II e III podemos observar os pontos médios da FM2 e FM3, respectivamente, com seus desvios padrões para os três comprimentos de onda na excitação do tecido.

A figura 15 mostra os valores médios e o desvio padrão para FM2 para o esmalte, dentina e cárie quando a forma de processamento utilizado foi a razão das áreas, enquanto que na figura 16 visualizamos os dados encontrados quando utilizamos a FM3. 


\begin{tabular}{|c|c|c|c|}
\hline \multirow{2}{*}{ Excitação } & $\begin{array}{c}\text { Média das razões e } \\
\text { Desvio padrão } \\
\text { (Cárie) }\end{array}$ & $\begin{array}{c}\text { Média das razões e } \\
\text { Desvio padrão } \\
\text { (Dentina) }\end{array}$ & $\begin{array}{c}\text { Média das razões e } \\
\text { Desvio padrão } \\
\text { (Esmalte) }\end{array}$ \\
\hline $442 \mathrm{~nm}$ & $43,3 \pm 13,0$ & $58,8 \pm 12,4$ & $112,8 \pm 38,8$ \\
\hline $532 \mathrm{~nm}$ & $21,4 \pm 12,5$ & $7,9 \pm 2,5$ & $10,1 \pm 3,2$ \\
\hline $632 \mathrm{~nm}$ & $44 \pm 40,7$ & $5 \pm 3,5$ & $4,4 \pm 2,5$ \\
\hline
\end{tabular}

Tabela II - Valores das médias das razões com seus desvios padrões para cárie, dentina e esmalte utilizando FM2.

\begin{tabular}{|c|c|c|c|}
\hline \multirow{2}{*}{ Excitação } & $\begin{array}{c}\text { Média das razões e } \\
\text { Desvio Padrão } \\
\text { (Cárie) }\end{array}$ & $\begin{array}{c}\text { Média das razões e } \\
\text { Desvio Padrão } \\
\text { (Dentina) }\end{array}$ & $\begin{array}{c}\text { Média das razões e } \\
\text { Desvio Padrão } \\
\text { (Esmalte) }\end{array}$ \\
\hline $442 \mathrm{~nm}$ & $0,8 \pm 0,3$ & $0,8 \pm 0,1$ & $2 \pm 0,8$ \\
\hline $532 \mathrm{~nm}$ & $2,4 \pm 1,3$ & $0,7 \pm 0,1$ & $0,8 \pm 0,1$ \\
\hline $632 \mathrm{~nm}$ & $25,3 \pm 26,4$ & $2,2 \pm 1,6$ & $2,2 \pm 1,3$ \\
\hline
\end{tabular}

Tabela III - Valores das médias das razões com seus desvios padrões para cárie, dentina e esmalte utilizando FM3. 


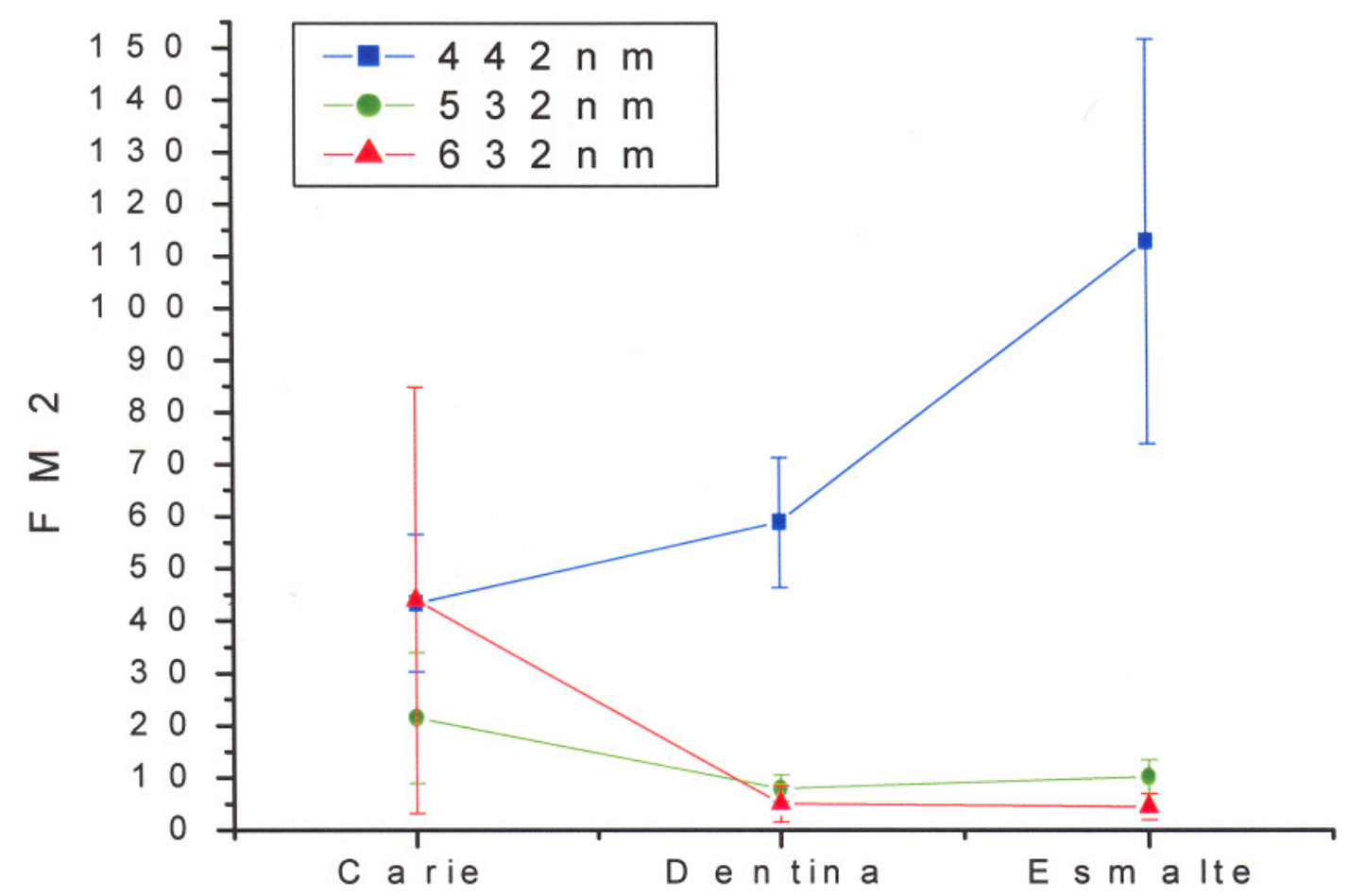

Figura 15 - Valor médio e desvio padrão para FM2 em cárie, dentina e esmalte

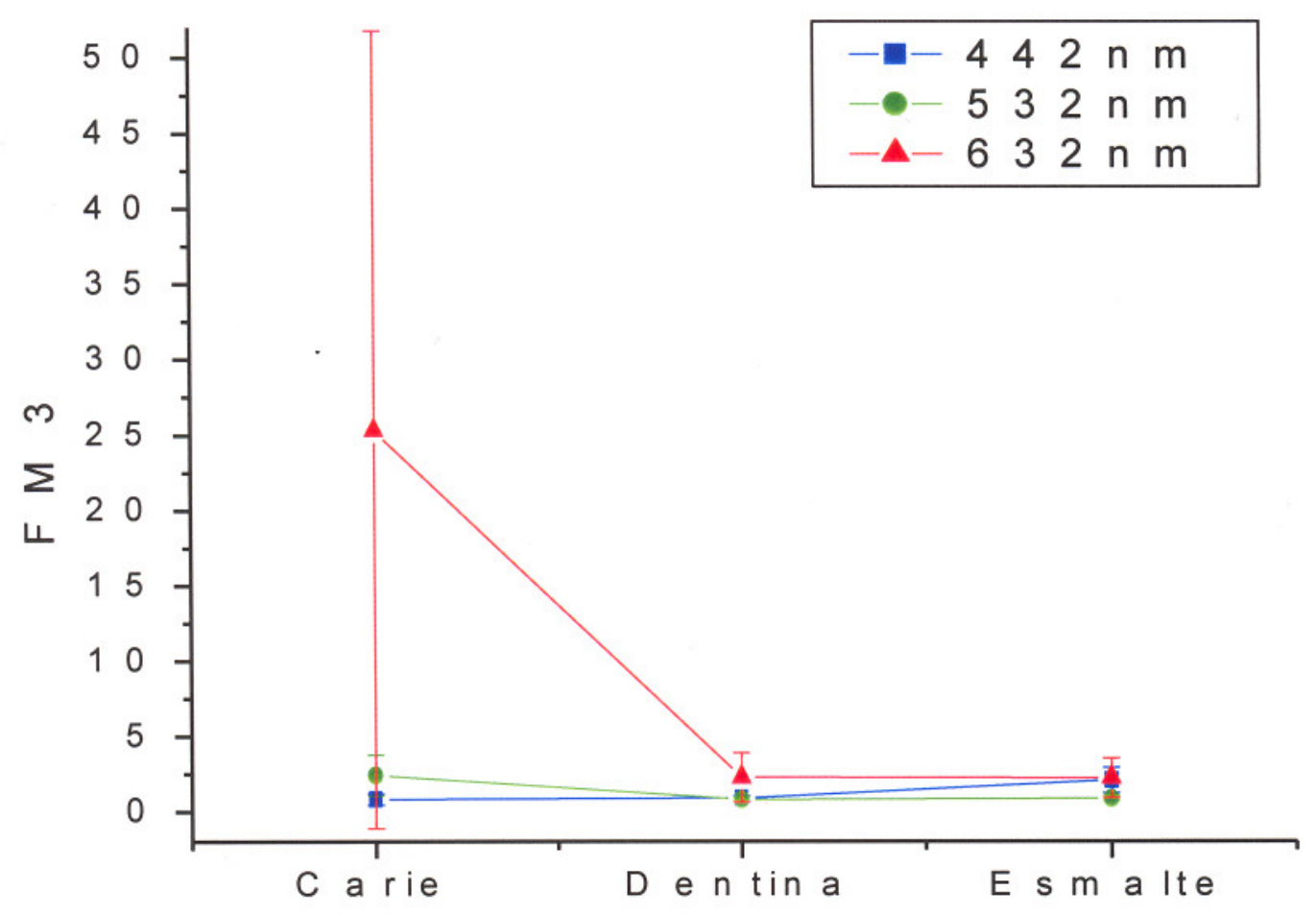

Figura 16 - Valor médio e desvio padrão para FM3 em cárie, dentina e esmalte 
Para determinar os melhores comprimentos de onda para o diagnóstico da cárie calculamos o contraste entre os tecidos cariado e sadio. Para determinar o contraste nessa metodologia utilizamos a seguinte equação:

$$
\text { Contraste }=\frac{\text { Tecido cariado }(F M)-\text { Tecido sadio }(F M)}{\text { Tecido sadio }(F M)}
$$

Os resultados encontrados para o contraste estão apresentados na tabela IV para FM2 (figura 17) e tabela V para FM3 (figura 18).

Os comprimentos de onda que apresentam os maiores contrastes são os mais favoráveis para o diagnóstico da cárie nessa metodologia empregada.

\begin{tabular}{|c|c|c|}
\hline Excitação & $\begin{array}{c}\text { Contraste (Cárie } x \\
\text { Dentina) }\end{array}$ & $\begin{array}{c}\text { Contraste (Cárie } x \\
\text { Esmalte) }\end{array}$ \\
\hline $442 \mathrm{~nm}$ & $-0,26$ & $-0,61$ \\
\hline $532 \mathrm{~nm}$ & 1,69 & 1,10 \\
\hline $632 \mathrm{~nm}$ & 7,66 & 8,79 \\
\hline
\end{tabular}

Tabela IV - Contraste para FM2 para excitação com 442, 532 e 632nm

\begin{tabular}{|c|c|c|}
\hline Excitação & $\begin{array}{c}\text { Contraste (Cárie } x \\
\text { Dentina) }\end{array}$ & $\begin{array}{c}\text { Contraste (Cárie } x \\
\text { Esmalte) }\end{array}$ \\
\hline $442 \mathrm{~nm}$ & $-0,07$ & $-0,61$ \\
\hline $532 \mathrm{~nm}$ & 2,04 & 1,82 \\
\hline $632 \mathrm{~nm}$ & 10,13 & 10,44 \\
\hline
\end{tabular}

Tabela V - Contraste para FM3 para excitação com 442, 532 e 632nm 


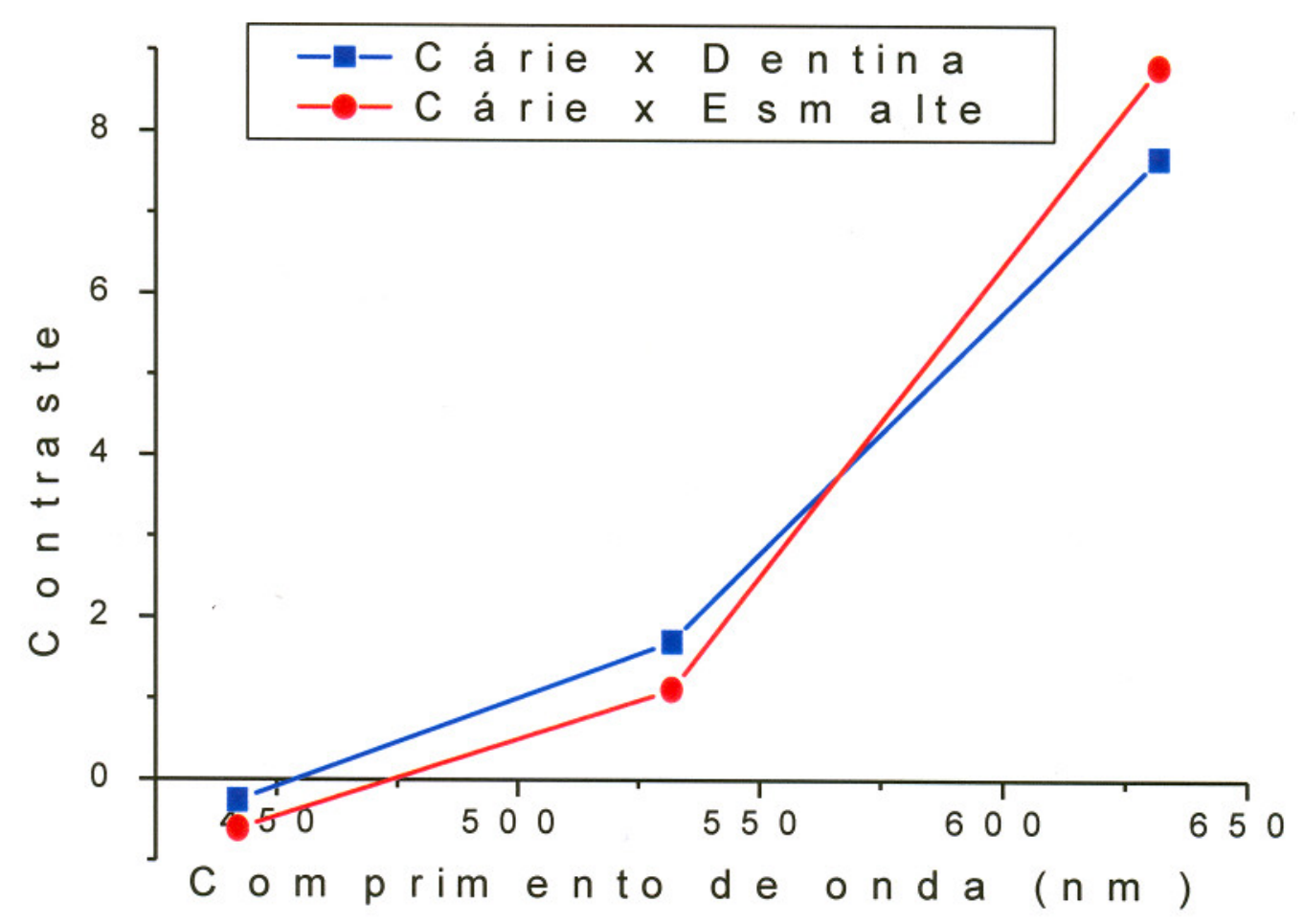

Figura 17 - Contraste para FM2

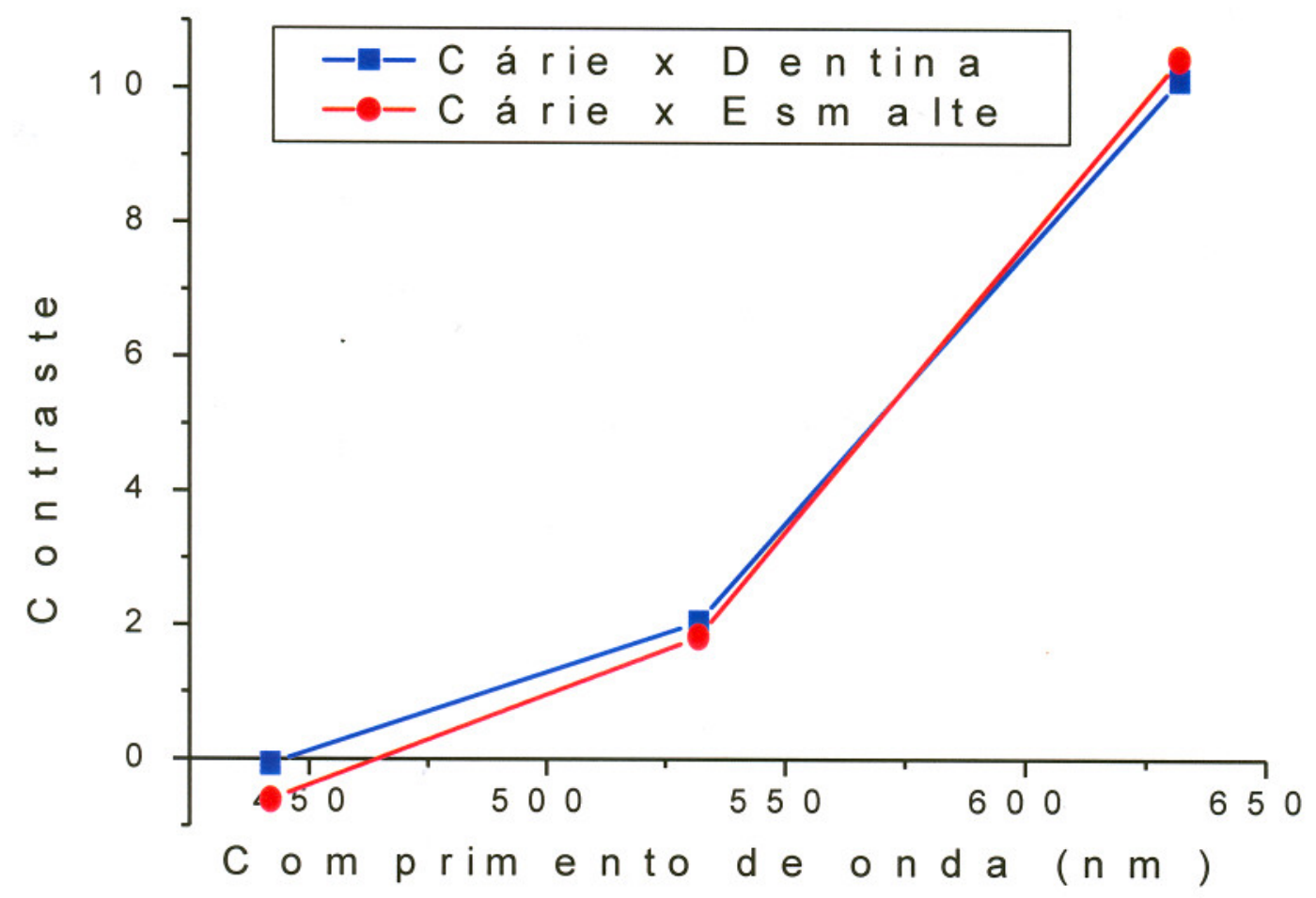

Figura 18 - Contraste para FM3 
Podemos observar que os três comprimentos de onda apresentam contraste para o diagnóstico de cárie, ou seja, todos os três comprimentos de onda possibilitam o diagnóstico da cárie.

Contudo, quando a excitação é realizada com $442 \mathrm{~nm}$ o contraste é muito próximo de zero. Porém, observamos que o tecido quando é excitado com $632 \mathrm{~nm}$ apresenta os maiores valores de contraste.

As figuras 17 e 18 mostram o contraste em função do comprimento de onda, sendo que existe uma faixa de comprimentos de onda que não apresentam contraste suficiente para o diagnóstico da cárie.

O comprimento de onda que apresentou o melhor contraste foi o de $632 \mathrm{~nm}$. Nessa excitação o tecido sadio apresenta baixa intensidade de fluorescência, enquanto o tecido cariado apresenta alta intensidade de fluorescência.

Os autores Masychev e Alexandrov, 2000 trabalharam com excitação em $632 \mathrm{~nm}$ em esmalte sadio, cárie rasa, cárie média e cárie profunda e demonstraram que a medida que aumentava a profundidade da cárie aumentava a intensidade da fluorescência. 


\section{III.7. CONCLUSÃO}

\section{III.7.1. FM2 e FM3}

Essas duas Figuras de Mérito (FM2 e FM3) avaliaram o processamento da fluorescência levando em consideração a área.

Os tecido cariado quando é excitado com 442 apresenta uma baixa intensidade de fluorescência quando comparada com os tecidos sadio.

Quando o tecido cariado é excitado com $632 \mathrm{~nm}$ e $532 \mathrm{~nm}$ apresenta alta intensidade de fluorescência quando comparado com os tecidos sadios.

Como foi verificado alteração nas intensidades de fluorescência entre os tecidos sadio e cariado processamos a FM2 com a área total da fluorescência em relação a área total da excitação.

$\mathrm{Na}$ FM3 a avaliação da fluorescência foi considerada apenas os comprimentos de ondas finais da fluorescência que vai de 700 a $840 \mathrm{~nm}$, pois foi observado que os tecidos sadios quando excitado com $632 \mathrm{~nm}$ apresentam baixa intensidade de fluorescência.

No processamento da área da fluorescência foi utilizado os três comprimentos de onda disponiveis: $442 \mathrm{~nm}, 532 \mathrm{~nm}$ e $632 \mathrm{~nm}$. Esses comprimentos de onda apresentaram-se favoráveis ao diagnóstico da cárie.

Quando a fluorescência gerada pelo comprimento de onda de $442 \mathrm{~nm}$ foi processado pela área, assim como, para FM2 e FM3 mostrou um contraste menor do que quando foi processado pela FM1. 
Foi possivel determinar com a metodologia empregada no processamento da fluorescência a existência de uma faixa nos comprimentos de onda de excitação do tecido que não mostram contraste para o diagnóstico da cárie.

Quando o tecido foi excitado com $532 \mathrm{~nm}$ e $632 \mathrm{~nm}$ mostrou melhores contrastes, sendo que o comprimento de onda de $632 \mathrm{~nm}$ obteve os melhores contrastes para FM2 e FM3. 
IV. EXPERIMENTO II

\section{EXPERIMENTO II}

Para caracterizar uma substância química é necessário que seja analisado todo o espectro da fluorescência, pois ao analisarmos isoladamente comprimentos de onda no espectro podemos estar sujeitos a resultados falso-positivos.

O aparelho comercial Diagnodent $\mathbb{B}$ analisa apenas um ponto no espectro de fluorescência, isso ocasiona erros em algumas medidas de cárie como é o caso de dentes pigmentados por corantes, onde o aparelho acusa a presença de cárie (Ribeiro, 2001).

Quando vamos realizar restaurações feitas a laser desejamos que nossa remoção de cárie seja conservadora, removendo apenas tecido cariado e preservando estrutura dental sadia.

O Diagnodent $\AA$ é um auxílio para o Cirurgião-Dentista no momento de diagnosticar cárie residual após o preparo cavitário. 


\section{IV.1. OBJETIVOS}

A partir da década de 80 a fluorescência começou a ser estudada com o intuito de utiliza-lá no diagnóstico da cárie. No final da década de 90 é lançado comercialmente um aparelho que realiza o diagnostico de cárie por fluorescência, esse aparelho é o Diagnodent@.

No final da década de 90 é aprovada a utilização do laser de Er:YAG na remoção de cárie.

Esses dois aparelhos contribuem para uma Odontologia mais conservadora, pois com $\circ$ Diagnodent $($ podemos monitorar processos cariosos evitando a utilização de materiais restauradores e podemos avaliar se ocorreu toda a remoção de tecido cariado após o preparo cavitário. Com o laser de Er:YAG aproveitamos sua precisão na remoção do tecido cariado e sua seletividade nessa remoção.

O objetivo desse trabalho é avaliar a utilização do laser de Er:YAG em esmalte sadio em conjunto com o Diagnodent $($ verificando se ocorrem alterações em suas medidas, pois após a irradiação com o laser de Er:YAG verificamos alterações nas propriedades ópticas do esmalte, pois aparenta uma cor brancoopaca. 


\section{IV.2. MATERIAIS E MÉTODOS}

\section{IV.2.1. DENTES}

Nessa segunda parte do experimento foram utilizados quinze molares permanentes humanos extraídos com a coroa dental íntegra e armazenados em soro fisiológico. Os dentes passaram por profilaxia com escova de Robson e água oxigenada em baixa rotação e depois lavados com soro fisiológico.

A área eleita para sofrer a irradiação com o laser de Er:YAG foi o esmalte dental em uma das superfícies lisas da coroa dental. A coroa não deveria apresentar cárie e o valor registrado pelo Diagnodent@ não deveria ultrapassar 07 antes da irradiação com o laser de Er:YAG.

\section{IV.2.2. PREPARAÇÃO DAS AMOSTRAS}

Os quinze dentes foram separados em cinco grupos de dentes com três dentes cada grupo. No momento de realizar as medidas com o Diagnodent $₫$, o laser de Er:YAG era ajustado nos parâmetros de irradiação pré-determinado para cada grupo.

O dente era removido do soro fisiológico e feito uma secagem com jato de ar por 10 s no local, onde seria promovida a irradiação, em seguida, a superfície era medida com o Diagnodent 8 . 
O sítio do dente escolhido para leitura com o Diagnodent( 8 foi sempre uma superfície lisa (vestibular ou palatina), onde a leitura com o Diagnodent não deveria ultrapassar 07.

Logo após, o dente era irradiado com laser de Er:YAG nos parâmetros de cada grupo sob refrigeração de água e ar. A distância focal do dente era de aproximadamente $1,5 \mathrm{~cm}$ que corresponde a distância focal do laser. $A$ área de irradiação do feixe è de $0,466 \mathrm{~mm}^{2}$.

Finalmente, os dentes eram secos com jato de ar por 10 s e realizado nova medida com o Diagnodent®.

Foram constituídos 5 grupos com 3 dentes cada grupo. Os parâmetros de irradiação de cada grupo foram:

- Grupo I - $100 \mathrm{~mJ}, 10 \mathrm{~Hz}$ e $15 \mathrm{~s}$,

- Grupo II - 200mJ, $10 \mathrm{~Hz}$ e 15s,

- Grupo III - 300mJ, 10Hz, 15s,

- Grupo IV - $400 \mathrm{~mJ}, 10 \mathrm{~Hz}, 15 \mathrm{~s}$ e

- Grupo V-500mJ, $10 \mathrm{~Hz}$ e $15 \mathrm{~s}$.

Cada grupo recebeu diferentes energias de irradiação, essa diferença produz condições de cavidades diferentes, ou seja, quanto maior a energia de irradiação maior será a profundidade da cavidade. 


\section{IV.2.3. DIAGNODENT®}

O Diagnodent $($ foi desenvolvido depois de um estudo feito por Hibst e Gall (1998) quando foi proposto como uma alternativa para o diagnóstico da cárie comparada com os métodos convencionais. Eles observaram que a intensidade da fluorescência diminui com o comprimento de onda, mas essa diminuição é muito mais pronunciada para o tecido sadio comparado com o esmalte e dentina cariados.

O Diagnodent $B^{2}$ excita o tecido dental com laser de diodo vermelho em $655 \mathrm{~nm}$ com potência menor ou igual a $1 \mathrm{~mW}$. O aparelho possui duas pontas $A$ e $B$, sendo usadas na superfície oclusal e lisa, respectivamente.

Esse sistema conduz cerca de $1 \mathrm{~mW}$ de luz com comprimento de onda de $655 \mathrm{~nm}$ e detecta o pico de fluorescência das porfirinas que podem ser detectadas na superfície do dente na região cariada (König et al., 1998).

É necessário que faça uma profilaxia no dente antes de realizar as medidas no dente, pois a placa bacteriana, alterações de cor e materiais de restauração podem alterar os resultados.

Antes de realizar as medidas na superfície do dente com o Diagnodent $(8)$ era realizada a calibração na cerâmica que acompanha o aparelho, sendo feita conforme indicação no manual do fabricante.

As medidas das superfícies dentais feitas com ○ Diagnodent 8 (KaVo Biberach - Alemanha) (figura 19) foram realizadas utilizando a ponta B, conforme indicado pelo fabricante para superficies lisas.

Inicialmente, removiamos o dente do soro e secávamos sua superfície com jato de ar por 10s, em seguida realizávamos a leitura da superfície do esmalte com - aparelho movimentando a ponta da sonda para determinar a maior leitura, conforme indicação do fabricante. 
Posteriormente, irradiávamos a amostra com laser de Er:YAG, então procedíamos a secagem da superfície com jato de ar por 10 s.

A seguir, realizávamos outra medida com o Diagnodent ${ }^{\circledR}$ movimentando a ponta da sonda para determinar a maior medida na área de irradiação.

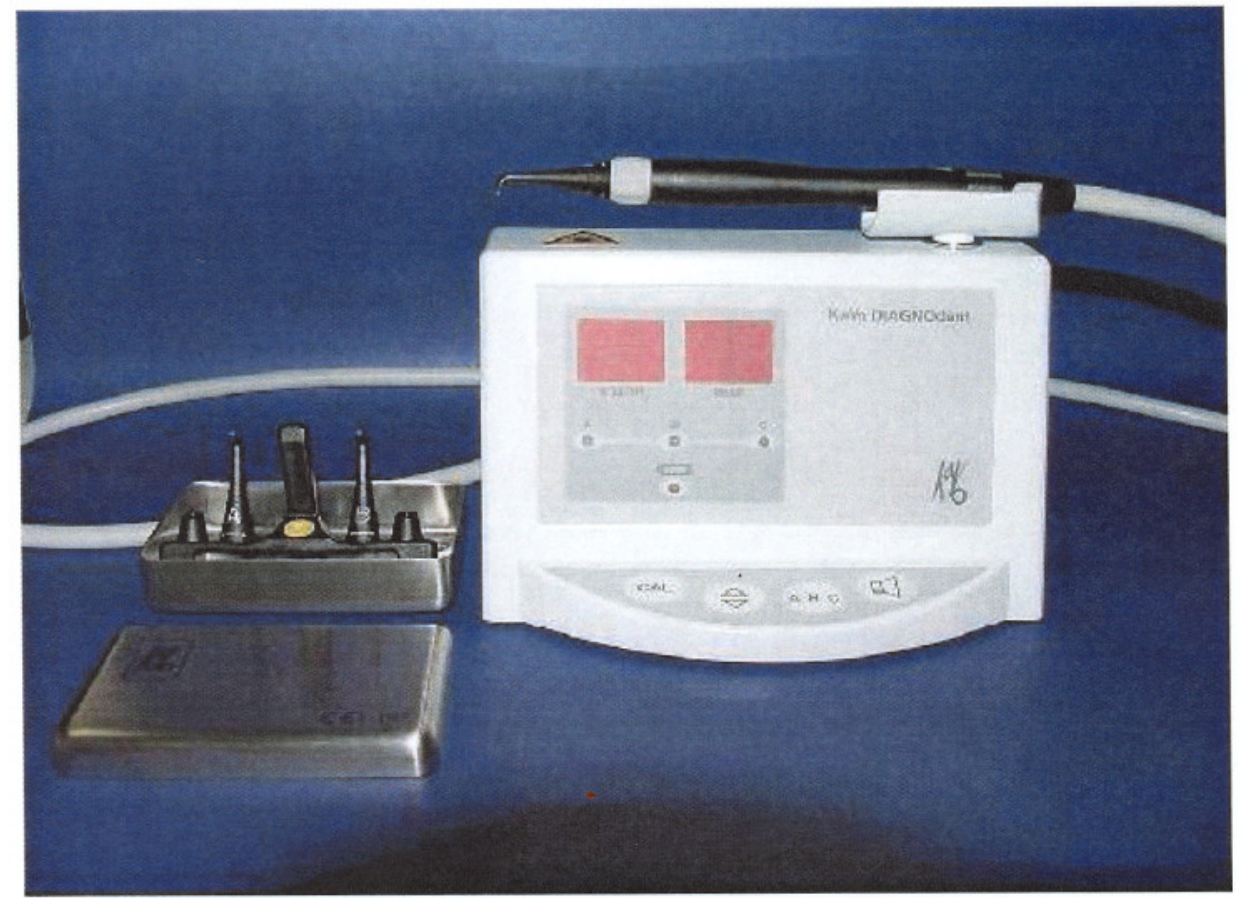

Figura 19 - Aparelho comercial Diagnodent@ utilizado no diagnóstico de cárie por fluorescência

\section{IV.2.4. LASER DE Er:YAG}

Os dentistas são treinados para preparar cavidades de Black, no entanto essas cavidades são invasivas para a estrutura dental e desenvolvidas para os materiais restauradores da época. 
Nessas cavidades é necessário a remoção de tecido sadio para realizar a restauração do dente independente do tamanho da lesão cariosa. Esse excesso de remoção é feito para que esses materiais de restauração suportem as forças mastigatórias, porém essa remoção desnecessária de tecido promove um enfraquecimento da estrutura dental.

Os compostos adesivos modernos estão mudando a Odontologia Restauradora, já que os preparos cavitários para esses novos materiais restauradores não são mais necessários, exigindo apenas a remoção do tecido cariado. Isso promove uma conservação da estrutura dental sadia, pois não necessita mais da remoção de tecido sadio para suportar o material de restauração.

O laser é um procedimento de remoção de cárie mais conservador do que os instrumentos rotatórios promovendo a limpeza e esterilização da cavidade por ablação. O comprimento de onda de $2940 \mathrm{~nm}$ coincide com o pico de absorção da água e é altamente absorvida pela hidroxiapatita (Mello; Mello, 2001). Como o tecido cariado possui um conteúdo de água maior que o tecido sadio a cárie é mais facilmente removida, isso faz com que haja uma preservação do tecido dental sadio.

Foi utilizado o laser TWNLIGHT (Fotona Medical Lasers, Slovenia) (figura 20) que possui dois sistemas de lasers de estado sólido integrados Er:YAG e Nd:YAG, com comprimentos de onda de $2940 \mathrm{~nm}$ e $1064 \mathrm{~nm}$, respectivamente, porém, nesse experimento utilizamos apenas o laser de Er:YAG.

O laser de Er:YAG é conduzido por um braço articulado até uma peça de mão, onde é direcionado ao sítio de tratamento, esse laser possui uma distância focal de $1,5 \mathrm{~cm}$ da peça de mão até o ponto de irradiação. Para o resfriamento do tecido a peça de mão possui uma saída de água e ar.

O sistema Twinlight utiliza dois lasers diferente para tratamento que operam na parte infravermelha do espectro eletromagnético. Possui um laser guia que 
opera na parte visível do espectro para guiar a operação. Os dois lasers são pulsados de estado sólido, um dos lasers é o Nd:YAG que opera em um comprimento de onda de $1064 \mathrm{~nm}$ e o outro laser é o Er:YAG que opera no comprimento de onda de $2940 \mathrm{~nm}$. A luz guia é produzido por um laser de diodo e opera no comprimento de onda de $670 \mathrm{~nm}$.

Cada uma das barras de cristal (Er:YAG - Érbio banhado em Ítrio-AlumínioGranada e Nd:YAG - Neodímio banhado em ltrio-Alumínio-Granada) estão colocadas entre dois espelhos.

Lâmpadas flash fornecem energia para as barras de cristal que excitam os íons de Érbio e Neodímio para promover a emissão estimulada de fótons. A energia laser sai através de um espelho parcialmente transmissor e entra em um sistema de condução do laser.

O laser de Er:YAG trabalha em um comprimento de onda de $2940 \mathrm{~nm}$ com duração de pulsos de 200 a $450 \mu$ m. Trabalha com uma freqüência de até $15 \mathrm{~Hz}$ com uma energia por pulso de até $500 \mathrm{~mJ}$, sendo ajustável pelo operador. A energia do laser de Er:YAG é transmitida através de um braço articulado com cinco espelhos que terminam em uma peça de mão que dirige o laser para o sítio de tratamento por um sistemas de espelhos e lentes. O sistema possui uma área focal de $0,466 \mathrm{~mm}^{2}$.

O laser de Er:YAG é altamente absorvido pela água e pela hidroxiapatita. Como a substância dental dura (esmalte, dentina e cemento) possui uma alta porcentagem de água e hidroxiapatita o tecido duro é removido eficientemente.

Como quase toda a energia é usada para ablação, o remanescente de calor é mínimo. Por tanto, o laser de Er:YAG é especialmente efetivo para remoção de dentina, esmalte e cemento.

A peça de mão do laser de Er:YAG é usada para transmitir com segurança a energia transmitida através do braço articulado até o sítio de tratamento. A peça de 
mão conta com uma saída simultânea de água e ar para promover o resfriamento e facilitar a ablação dos tecidos.

O fluxo de saída de água na peça de mão estava ajustada para $0,14 \mathrm{ml} / \mathrm{s}$ (ou $8,4 \mathrm{ml} / \mathrm{min}$ ), a ponta ativa do laser possui um diâmetro de $700 \mu \mathrm{m}$ com uma ponta de não contato com a janela em safira.

O laser de Er:YAG está estabelecido como instrumento capaz de promover uma remoção seletiva e precisa de tecidos dentais cariados. A remoção de tecido cariado com o laser de Er:YAG minimiza a perda de tecido dental sadio, por ser seletivo, além de promover uma sessão mais confortável aos pacientes, pela ausência de vibração e aquecimento.

O laser de Er:YAG está estabelecido como instrumento capaz de promover uma remoção seletiva e precisa de tecidos dentais cariados. A remoção de tecido cariado com o laser de Er:YAG minimiza a perda de tecido dental sadio, por ser seletivo, além de promover uma sessão mais confortável aos pacientes, pela ausência de vibração e aquecimento.

Hibst e Keller (1989) mediram a profundidade e diâmetro de orifícios produzidos pela aplicação do laser de Er:YAG em função do número de pulsos e energia de exposição. As crateras em esmalte foram menores que em dentina, sendo que ambos tiveram grosseiramente a forma de um cone. $O$ diâmetro das crateras indicou um maior limiar para a remoção do esmalte que a dentina, a profundidade da cratera em esmalte pode ser linearmente relacionada à radiação por pulso. Um pulso simples de laser de Er:YAG de $400 \mathrm{~mJ}\left(50 \mathrm{~J} / \mathrm{cm}^{2}\right)$, determinou um pequeno aumento de temperatura muito localizado. Após $0,1 \mathrm{~s}$, a temperatura da cratera foi de $50^{\circ} \mathrm{C}$ e houve retorno à temperatura ambiente em 2 segundos. Calcularam o tempo de vaporização em 2 microssegundos tanto para dentina como para o esmalte, considerando-se uma exposição de $40 \mathrm{~J} / \mathrm{cm}^{2}$. 
Burkes et al. (1992) estudaram as alterações de temperatura e o efeito da refrigeração durante a aplicação do laser de Er:YAG em pré-molares e molares humanos hígidos extraídos. Sob refrigeração a ar, a ablação foi ineficiente nos parâmetros de $58 \mathrm{~mJ}$ de energia, $10 \mathrm{~Hz}$, com pulso de $2,5 \mu$ s. Não conseguindo formar uma cavidade, mesmo após 4000 pulsos em 6,6 minutos, pois nenhuma estrutura foi removida após os primeiros pulsos em um mesmo local. A microscopia eletrônica de varredura evidenciou grandes flocos de cinzas e a não existência de um padrão uniforme de ablação. Quando a irradiação sem refrigeração ocorreu, notou-se intensa fusão e escoamento do esmalte com vazios em forma de bolhas, grandes fendas e fissuras irregulares. A ablação com refrigeração a água, nos mesmos parâmetros, foi eficiente. A energia de 8397 pulsos, em aproximadamente 12 minutos, produziu preparos cavitários semelhantes aos convencionais em forma e tamanho. A superfície de esmalte nas margens da ablação, mostrou-se fraturada, com bordas e arestas cortantes. Nenhuma fusão ou arredondamento dos bordos do esmalte remanescentes foi percebido, com a refrigeração a água. Diferença de temperatura atingida durante a aplicação entre os dois grupos foi significante. Amostras tratadas com refrigeração a ar chegaram a atingir mais de $20^{\circ} \mathrm{C}$ de aumento de temperatura, enquanto que as refrigeradas com água elevaram em média $4^{\circ} \mathrm{C}$. A adição de água à refrigeração, não só melhorou a ablação como também conferiu proteção térmica à polpa.

Li et al. (1992) avaliaram a eficiência de ablação do laser de Er:YAG em esmalte e dentina de elementos dentais humanos inteiros, assim como em secções

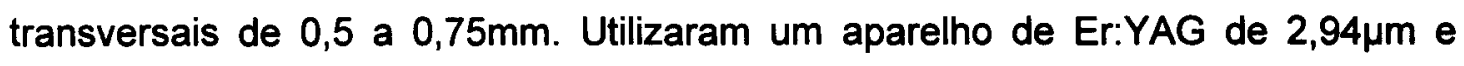
pulso de $200 \mu \mathrm{s}$, sob refrigeração de spray de água. Após a ablação, as perfurações obtidas foram observadas em microscopia de luz e medidas em um micrômetro ocular. Fluências de 10 a $140 \mathrm{~J} / \mathrm{cm}^{2}$ obtiveram profundidades de ablação em esmalte de 37 a $75 \mu \mathrm{m}$ por pulso, isso para $2 \mathrm{~Hz}$. Aumentando a frequência para $5 \mathrm{~Hz}$ 
e fluências de 50 a $115 \mathrm{~J} / \mathrm{cm}^{2}$, a profundidade de ablação esteve entre 50 e $74 \mu \mathrm{m}$ por pulso. As diferenças de profundidade observadas entre o elemento inteiro e as secções transversais talvez possam ser explicadas pela direção da energia incidente relativamente à direção dos prismas de esmalte. Nas secções transversais de esmalte, a energia radiante estava aproximadamente perpendicular aos prismas de esmalte, enquanto que na superficie vestibular do dente inteiro, o feixe estava quase paralelo aos prismas. O limiar para ablação de esmalte foi calculado como sendo $7,2 \mathrm{~J} / \mathrm{cm}^{2}$ para $5 \mathrm{~Hz}$ e $18,6 \mathrm{~J} / \mathrm{cm}^{2}$ para $2 \mathrm{~Hz}$. Quanto maior a frequência, maiores podem ser os efeitos térmicos induzidos pelo laser. Quanto à morfologia, descreveram as perfurações obtidas como cônicas, explicadas pela convergência do laser. A área adjacente às perfurações esteve livre de carbonização para todas as fluências abaixo de $80 \mathrm{~J} / \mathrm{cm}^{2}$. Acima desses niveis apareceu ao redor das perfurações uma zona amarela clara de 10 a $15 \mu \mathrm{m}$. Apresentaram fotomicrografias de varredura de secção longitudinal de uma perfuração em esmalte dental humano, evidenciando superfície com rugosidade, porém, sem carbonização. O maior aumento evidenciou a normalidade dos cristalitos de esmalte da perfuração. Provavelmente a irregularidade superficial apresentada pelo orificio poderia ser benéfica para procedimentos adesivos.

Hibst e Keller (1993) investigaram o mecanismo de ablação induzido pelo laser de Er:YAG em tecidos duros. Considerando fotografias tomadas durante a irradiação do laser, percebeu-se que a ablação dos tecidos duros não era uma única explosão, mas uma remoção contínua de material durante a irradiação. Para pulsos de alta energia $(300 \mathrm{~mJ}, 500 \mathrm{~mJ})$, a ejeção das particulas teve início dentro de $1 \mu \mathrm{s}$, após o começo da irradiação. Os debris foram ejetados do esmalte dentro de um cone de $20^{\circ}$ a $30^{\circ}$. Trabalhando próximo do limiar de ablação com pulsos de $20 \mathrm{~mJ}$, ocorreu um atraso de $35 \mu$ s na ejeção das partículas do esmalte. A ablação das substâncias dos tecidos duros aconteceram na forma de pequenos fragmentos 
de esmalte e dentina sendo ejetadas, em velocidade de algumas dezenas de metro por segundo. Este processo pode ser causado pela repentina evaporação da água contida no próprio esmalte e dentina. A pressão interna aumentaria, quebraria tecidos duros e, o vapor se expandindo, aceleraria os fragmentos resultantes. Assim, o material seria removido sem passar pela fusão ou pela vaporização dos tecidos duros. As observações revelaram que a ablação dos tecidos duros com o Er:YAG ocorreu inicialmente, sem que a fusão dos componentes dos tecidos sólidos se procedesse.

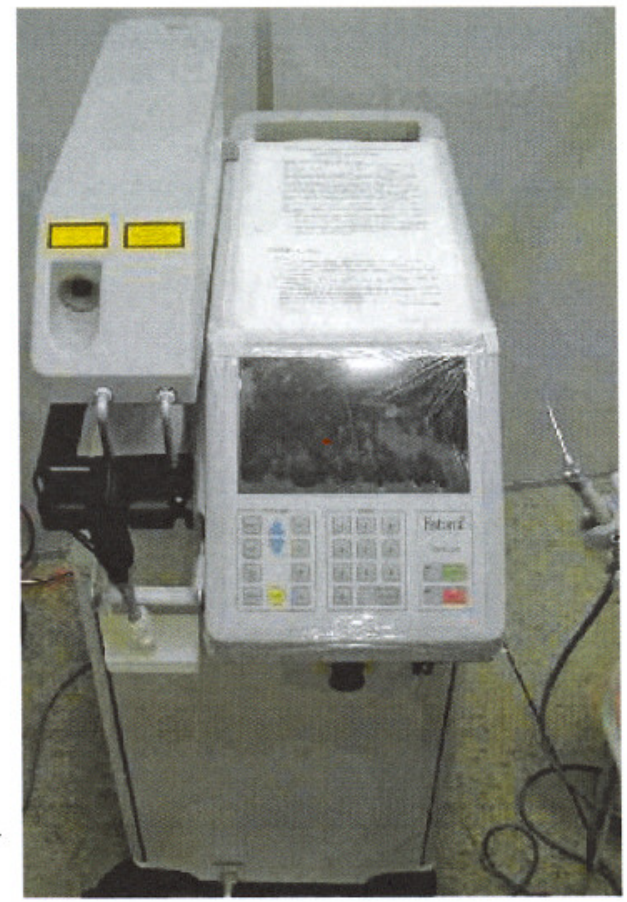

Figura 20 - Laser de Er:YAG (TWINLIGHT - Fotona Medical Lasers, Slovenia) 


\section{IV.2.5. PROCESSAMENTO DOS DADOS}

Primeiramente foi realizado uma leitura em esmalte sadio numa superfície lisa com o Diagnodent $(B$ antes da irradiação com laser de Er:YAG, a medida máxima nessa superfície antes da irradiação deveria ser de 07.

Essa superfície era irradiada com o laser de Er:YAG e em seguida era feita outro leitura com o Diagnodent $\$$ no local irradiado.

Para processar os valores obtidos das medidas do dente com o Diagnodent 8 foram obtidos as médias das leituras e calculado o desvio padrão para cada grupo antes e depois da irradiação com o laser de Er:YAG.

Para uma melhor visualização dos dados esses foram dispostos em um gráfico de energia de irradiação em função do escore do Diagnodent®.

\section{IV.3. RESULTADOS E DISCUSSÃO}

Nesse experimento o esmalte foi irradiado com o laser de Er:YAG e realizado medidas com o Diagnodent@e pré e pós irradiação, sendo possivel observar um aumento nos valores dos escores após a irradiação do esmalte.

Após a irradiação com o laser de Er:YAG no esmalte ocorre uma alteração nas propriedades ópticas do tecido dental, pois torna-se branco-opaco. Essa alteração de cor é decorrente de alteração da reflexão da luz.

O Diagnodent国 faz o diagnóstico por alterações ópticas que ocorrem no tecido sadio. Com a alteração da reflexão da luz no tecido sadio induz a erros na medida do tecido dental. 
Provavelmente, a medida do Diagnodent $\sqrt{ }$ por fluorescência ocorre por comparação da intensidade de dois comprimentos de onda. Com a alteração na propriedade óptica do tecido, quando o aparelho compara a intensidade de fluorescência com o outro comprimento de onda ocorre erro por ter alterado as propriedades de reflexão do tecido.

Observou-se que o aumento no escore do Diagnodent@ após a irradiação com o laser de Er:YAG era proporcional ao aumento da energia de irradiação.

$\mathrm{Na}$ tabela VI (figura 21) está contido o valor dos escores pré e pós-irradiação em função da energia de irradiação com o laser. Através da figura 21 observamos que antes de ser aplicado o laser de Er:YAG no tecido, há uma linearidade na reta.

Entretanto, após a aplicação do laser ocorre uma alteração nas propriedades ópticas do tecido e esse passa a apresentar um aspecto brancoopaco. Com essas alterações ópticas o Diagnodent $\Theta$ passa a registrar um aumento na medida dos escores após ser feita a irradiação com o Er:YAG.

Antes da aplicação do laser observamos na tabela VI que as medidas nos dentes não ultrapassaram o valor 07 , ou seja, esses dentes seriam classificados como dentes com o esmalte sadio.

Porém, após a aplicação com o laser de Er:YAG o Diagnodent@ passou a acusar escores mais elevados com um aumento de $220 \%, 1216 \%, 1541 \%, 877 \%$ e $1908 \%$ para os Grupos 1, 2, 3, 4 e 5, respectivamente.

O Diagnodent( registrou alteração nas medidas com um aumento progressivo até $300 \mathrm{~mJ}$, acima dessa intensidade de energia encontramos uma saturação.

Nesse experimento observamos que o Diagnodent $\Theta^{3}$ acusou cárie em um sítio que não existia a lesão, somente a cavidade. Quando utilizamos o laser de Er:YAG queremos aproveitar sua característica conservadora na remoção de tecido cariado. 
Entretanto, fazendo a remoção da cárie em esmalte com o laser, o Diagnodent $₫$ não deve ser o único meio de monitoramento, pois pode levar a uma grande remoção de tecido sadio.

Isso demonstra que o Diagnodent não deve ser utilizado como uma ferramenta de diagnóstico, mas como um meio complementar no diagnóstico.

\begin{tabular}{|c|c|c|}
\hline Energia de Irradiação & Escore Pré-irradiação & Escore Pós-irradiação \\
\hline \multirow{3}{*}{ Grupo $1-100 \mathrm{~mJ}$} & 03 & 08 \\
\hline & 03 & 12 \\
\hline & 04 & 12 \\
\hline \multirow{3}{*}{ Grupo $2-200 \mathrm{~mJ}$} & 04 & 57 \\
\hline & 04 & 55 \\
\hline & 04 & 46 \\
\hline \multirow{3}{*}{ Grupo $3-300 \mathrm{~mJ}$} & 02 & 99 \\
\hline & 07 & 80 \\
\hline & 05 & 51 \\
\hline \multirow{3}{*}{ Grupo $4-400 \mathrm{~mJ}$} & 07 & 61 \\
\hline & 07 & 60 \\
\hline & 04 & 55 \\
\hline \multirow{3}{*}{ Grupo $5-500 \mathrm{~mJ}$} & 03 & 82 \\
\hline & 04 & 62 \\
\hline & 05 & 97 \\
\hline
\end{tabular}

Tabela VI - Medidas com o Diagnodent® (pré e pós-irradiação com Er:YAG) 


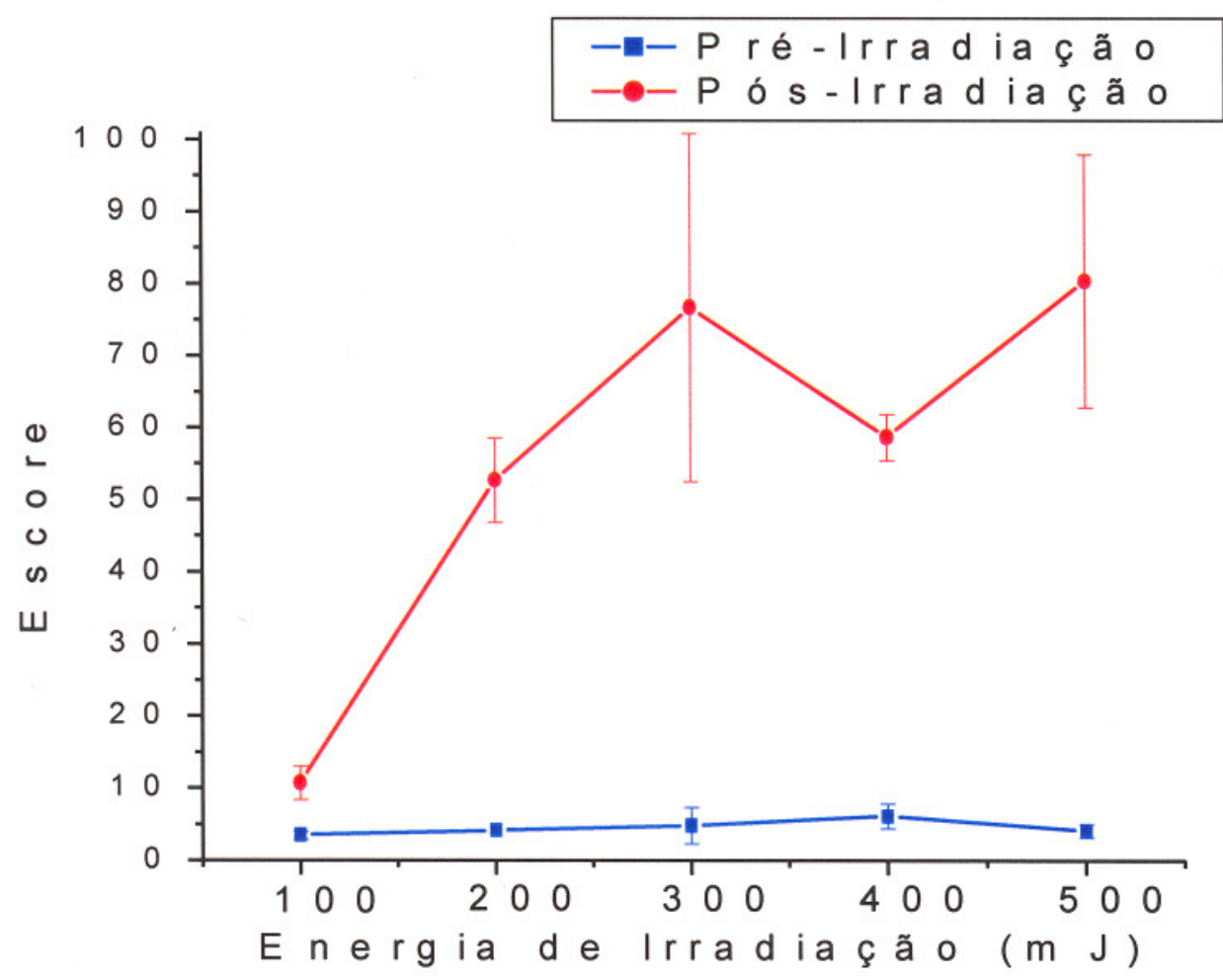

Figura 21 - Escore do Diagnodent $₫$ por energia de irradiação com laser de Er:YAG 


\section{IV.4. CONCLUSÃO}

\section{IV.4.1. EXPERIMENTO II}

Quando realizamos restaurações feitas à laser desejamos aproveitar as características de seletividade pelo tecido cariado, ou seja, removendo apenas à cárie e preservando a estrutura dental sadia, pois os materiais de restauração resinosos não exigem uma sobre remoção de tecido, como é o caso do amálgama.

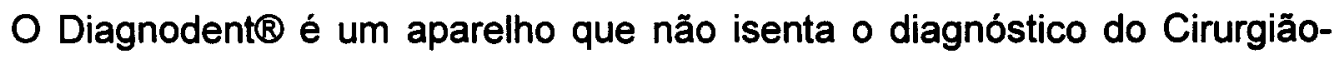
Dentista em relação à cárie, pois apresenta desvantagens indicando diagnósticos falso-positivos como mostrado no trabalho de Ribeiro (2001) mostrando um aumento nas medidas em dentes que sofreram pigmentações com corante. Ocorrendo, também, alterações em suas medidas quando há a presença de placa bacteriana.

Nesse experimento avaliamos as alterações que ocorrem nas medidas com

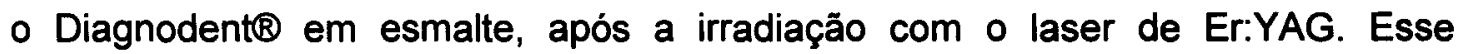
experimento demonstra uma desvantagem na utilização do Diagnodent $(8$, pois esse aparelho apresenta diagnóstico falso-positivo no esmalte irradiado com o laser de Er:YAG.

Isso pode levar a uma remoção desnecessária do tecido dental sem cárie, consequentemente, não aproveitando todas as vantagens que um preparo cavitário com laser pode oferecer que é a remoção seletiva de tecido cariado. 
V. CONCLUSÃO GERAL

\section{CONCLUSÃO GERAL}

Os métodos ópticos no diagnóstico da cárie apresentam a vantagem de não ser um método destrutivo e não promover alteração nas características do tecido analisado. Assim, a fluorescência está sendo estudada e usada para o diagnóstico da cárie.

Nesse trabalho foi possivel concluir que os comprimentos de onda de $442 \mathrm{~nm}, 532 \mathrm{~nm}$ e $632 \mathrm{~nm}$ apresentam contraste para o diagnóstico da cárie quando o método de processamento da fluorescência utilizado foi análise da razão dos picos ou da razão das áreas.

O comprimento de onda de $632 \mathrm{~nm}$ apresentou os mais altos contrastes nas duas metodologias empregadas. No entanto, pela análise do contraste das FM podemos observar que existe uma faixa nos comprimentos de onda que não existe ou esse contraste está muito próximo de zero para o diagnóstico da cárie.

O comprimento de onda de $442 \mathrm{~nm}$ apresentou contrastes bons quando foi feito a análise dos picos, porém quando foi feito o processamento pela área o contraste ficou muito próximo de zero.

Quando o tecido é excitado com $442 \mathrm{~nm}$ o tecido cariado apresenta baixa intensidade de fluorescência quando comparado com os tecidos sadios. 
Porém, quando o tecido cariado é excitado com $532 \mathrm{~nm}$ e $632 \mathrm{~nm}$ apresentam alta intensidade de fluorescência quando comparado com os tecidos sadios.

Com a excitação em $442 \mathrm{~nm}$ a fluorescência do esmalte é mais intensa que a fluorescência da dentina, porém quando vamos para $532 \mathrm{~nm}$ a intensidade do esmalte continua sendo mais intensa que a dentina, porém a intensidade é muito menor. Com $632 \mathrm{~nm}$ a intensidade da dentina e do esmalte são praticamente a mesma e muito próximo de zero.

Quando os tecidos sadios são excitados com $632 \mathrm{~nm}$ sua intensidade de fluorescência é muito baixa, sendo quase inexistente a fluorescência.

O Diagnodent é um aparelho comercial que utiliza a fluorescência para o diagnóstico da cárie e tem apresentado bom indice de sucesso, porém deve ser utilizado como uma ferramenta de diagnóstico auxiliar, pois pode apresentar diagnósticos falso-positivos em determinadas situações, como é mostrado nesse experimento, onde o esmalte é irradiado pelo laser de Er:YAG.

Devem ser feitas várias medidas no tempo, com o Diagnodent $\Theta$, no sítio avaliado para poder chegar a uma conclusão mais precisa a respeito da presença ou ausência de cárie.

A fluorescência mostra ser uma ferramenta útil em vários campos da ciência e vem ganhando espaço no diagnóstico de lesões cariosas devido a sua precisão. Porém, é necessário a compreensão de todo o espectro da fluorescência, pois, assim poderemos alcançar diagnósticos de lesões cariosas mais precisos. 


\section{REFERÊNCIA BIBLIOGRÁFICA}

\section{REFERÊNCIA BIBLIOGRÁFICA}

1. Alfano RR; Yao SS. Human teeth with and without dental caries studied by visible luminescent spectroscopy. J Dent Res, February, 120-122, 1981.

2. Almeida-Lopes L; Figueiredo ACR; Lopes $A$. $O$ uso do laser terapêutico no tratamento da inflamação na clínica odontológica através da drenagem linfática - Resumo. Revista da APCD, v.56, supl., p.27, 2002.

3. Angmar-Månsson B; Al-Khateeb S; Tranaeus S. Monitoring the caries process Optical methods for clinical diagnosis and quantification of enamel caries. Eur.J. Oral Sci. 104, 480-485, 1996.

4. Attrill DC; Ashley PF. Occlusal caries detection in primary teeth: a comparison of DIAGNOdent with conventional methods. British Dental Journal, 190, 440-443, 2001.

5. Bjelkhagen $H$; Sundström $F$; Angmar-Månsson B; Rydén $H$. Early detection of enamel caries by yhe luminescent excited by visible laser light. Swed Dent J, 6 , 1-7, 1982.

6. Brugnera Jr A; Pinheiro ALB. Lasers na Odontologia moderna, Pancast Editora, 356p., 1998.

7. Burkes, EJ; Hoke, J; Gomes, E; Wolbarsht, M. Wet versus dry enamel ablation by Er:YAG laser. J Prosthet Dent, v.67, n.6, 847-851, 1992.

8. Cangussu MCT; Castellanos RA; Pinheiro MF; Albuquerque SR de; Pinho C. Cárie dentária em escolares de 12 e 15 anos de escolas públicas e privadas de Salvador, Bahia, Brasil em 2001. Pesqui Odontol Bras, 16(4):379-384, 2002.

9. Chaves MAL. Laser e diagnóstico de cáries: estado da arte e avaliação in vitro das diferenças de fluorescência entre esmalte sadio e cariado. Dissertação de mestrado profissionalizante, 2001. 
10. Dichtl S, Baumgartner A; Hitzenberger CK; Moritz A; Wernisch J; Robl B; Sattmann $\mathrm{H}$; Leitgeb $\mathrm{R}$; Sperr W; Fercher AF. Imaging of dental material by polarization sensitive optical coherence tomography. SPIE, v.3593,p. 169-176, 1999.

11. Duarte D; Fonseca YPC; Zanin F; Brugnera Jr A. Deciduos teeth occlusal caries detection with $655 \mathrm{~nm}$ diode laser confirmed by surface scanning electron microscopy. SPIE, v.3910, 2000.

12. Eduardo, CP et al. Scanning electron microscopy study on enamel etching with Nd:YAG laser and phosphoric acid. J Clin Laser Med Surg, v.13, n.2, 81-85, 1995.

13. Everett MJ; Colston BW; Sathyam US; Da Silva LB. Non-invasive diagnosis of early caries with polarization sensitive optical coherence tomography (PS-OCT). SPIE, v.3593, 177-182, 1999.

14. Featherstone JDB. Caries detection and prevention with laser energy. Dental Clinics of North America, v. 44, n4, 955-969, 2000.

15. Featherstone JDB; Young DA. Need for new caries detection methods. SPIE vol. 3593, p.134-140, 1999.

16. Fennis-le YL; Verdonschot EH; van't Hof MA. Performance of some diagnostic system in the prediction of occlusal caries in permanent molars in 6- and 11year-old children. Journal of Dentistry, 26, 403-408, 1998.

17. Ferreira CM; Brandão CG; Bramante CM. Uso do laser DIAGNOdent no diagnóstico de cárie. RBO, v.58, n.1, 2001.

18. Figueiredo ACR; Almeida-Lopes L; Bagnato VS. Tratamento do herpes simplex com laserterapia segundo a fase da doença - Resumo. Revista da APCD, v.56, supl., p.25, 2002a.

19. Figueiredo ACR; Bagnato VS. Aplicação da espectroscopia de fluorescência no diagnóstico da cárie - Resumo. Revista da APCD, v.56, supl., p.25, 2002 b.

20. Figueiredo ACR; Bagnato VS. Diagnóstico de cárie por espectrometria de fluorescência - Resumo do XII Congresso Internacional de Odontologia do Triângulo Mineiro e Alto Paranaíba, resumo em CD-ROM, 2002c.

21. Figueiredo ACR; Bagnato VS. Optimização da excitação para diagnóstico de cárie por fluorescência - Resumo. Pesqui Odontol Bras, v.16, supl, p.255, 2002d.

22. Figueiredo ACR; Kurachi C; Bagnato VS. Processamento da fluorescência em esmalte, dentina e cárie - Resumo do Simpósio em Ciência e Engenharia de 
Materiais da Interunidades Ciência e Engenharia de Materiais da USP - São Carlos, p.59, 2002e.

23. Garber, DA. Dentist-monitored bleaching: a discussion of combination and laser bleaching. J Am Dent Assoc, v.128, suppl, 26s-30s, 1997.

24. Goldman, HM; Ruben, MP; Sherman, D. The application of laser spectroscopy for the qualitative and quantitative analyses of the inorganic components of calcified tissues. Oral Surg Oral Med Oral Pathol, v17, n1, 102-103, 1964a.

25. Goldman, L. et al. Impact of the laser on dental caries. Nature, v.203, n.4943, 417, $1964 b$.

26. Granville-Garcia AF; Araujo FB; Tovo MF. Estudo dos métodos visual, radiográfico interproximal e a laser no diagnóstico da cárie. Rev APCD, 54(5), 384-389, 2000.

27. Hafström-Björkman U; Sundström F; Angmar-Månsson B. Initial caries diagnosis in rat molars, using laser fluorescence. Acta Odontol Scand, v.49, n.3, p.27-33, 1991b.

28. Hafström-Björkman U; Sundström F; de Josselin de Jong E; Oliveby A; AngmarMånsson B. Comparison of laser fluorescence and longitudinal microradiography for quantitative assessment of in vitro enamel caries. Caries Res, 26, 241-247, 1992.

29. Hafström-Björkman U; Sundström F; ten Bosch JJ. Fluorescence in dissolved fractions of human enamel. Acta Odontol Scand, 49, n.3, p.133-138, 1991 a.

30. Hibst R; Gall R. Development of a diode laser-based fluorescence caries detector - Abstracts. Caries Res, 32, 294, 1998.

31. Hibst R; Paulus R. A new approach on fluorescence spectroscopy for caries detection. SPIE, v.3593, p.141-147, 1999.

32. Hibst, R; Keller, U. Experimental studies of the applicacion of the Er:YAG laser on dental hard substances: I. Measurement of the ablation rate. Laser Surg Med, v.9, n.4, 338-344, 1989.

33. Hibst, R; Keller, U. The mechanism of Er:YAG laser induced ablation of dental hard substances. In: Gal, D; O'Brien, SJ; Vangsness, CT; White, JM; Wigdor, HA (Eds.) Lasers in Orthopedic, Dental, and Veterinary Medicine II. Los Angeles: SPIE 1880, 156-162, 1993.

34. Jones FH. Teeth and bones: applications of surface science to dental materials and related biomaterials. Surface Science Reports, 42, 75-205, 2001.

35. Kairalla EC; Lage-Marques JL; Rode SM. Avaliação de métodos de diagnóstico da lesão de cárie. Ver Odontol Univ São Paulo, v.11, p27-34, suplemento, 1997. 
36. Kavo. Manual de instruções - KaVo DIAGNOdent 2095. 39p.

37. Kelsey, WP et al. Enhancement of physical properties of resin restorative materials by laser polimerization. Laser Surg Med, v.9, n.6, 623-627, 1989.

38. Keyes. In: KRIGER $L$ et al. ABOPREV - Promoção de saúde bucal. Artes Médicas, 475p, 1997.

39. König K; Schneckenburger $\mathrm{H}$; Hibst $\mathrm{R}$. Time-gated in vivo autofluorescence imaging of dental caries. Cell Mol Biol, 45(2), 233-239, 1999.

40. Li, Z; Code, JE; Van de Merwe, WP. Er:YAG laser ablation of enamel and dentin of human teeth: Determination of ablation rates at various fluences and pulse repetition rates. Lasers Surg Med, v.12, n.6, 625-630, 1992.

41. Lizarelli RFZ.; Bregagnolo JC; Lizarelli RZ; Palhares JMC.; Villa GEP.; Bagnato VS. Comparative diagnosis in the detection of decays involving conventional methods, laser and digital X-ray. SPIE, v3910, 219-226, 2000.

42. Loesche WJ. Role of Stretococcus mutans in human dental decay. Microbiological Review, v.50, n.4, p.353-380, 1986.

43. Longbottom $C$. Caries detection - current status and future prospects using lasers. SPIE, v.3910, 212-218, 2000.

44. Lussi A; Imwinkelried S; Pitts NB; Longbottom C; Reich E. Performance and reproducibility of a laser fluorescence system for detection of occlusal caries in vitro. Caries Res, 33, 261-266, 1999.

45. Lussi A; Megert B; Longbottom C; Reich E; Francescut P. Clinical performance of laser fluorescence device for detection of occlusal caries lesions. Eur J Oral Sci, 109, 14-19, 2001.

46. Marshall Jr GW; Marshall SJ; Kinney JH; Balooch $M$. The dentin substrate: structure and properties related to bonding. Journal of Dentistry, v.25, n6, p.441458, 1997.

47. Masychev VI; Alexandrov MT. Express-diagnostics of intact and pathological dental hard tissues by optical PNC-method. SPIE, v.3910, 2000.

48. Masychev VI; Sokolovsky AA; Kesler G; Alexandrov MT. Early dental caries detection by method of PNC-diagnostics. Comparison with visual and $\mathrm{X}$-ray methods. SPIE, v.3910, 269-280, 2000.

49. Matsumoto $\mathrm{H}$; Kitamura $\mathrm{S}$; Araki T. Autofluorescence in human dentine in relation to age, tooth type and temperatura measured by nanosecond timeresolved fluorescence microscopy. Archives of Oral Biology, 44, 309-318, 1999.

50. Matsumoto, K. Tooth pain control by laser. In: Internacional congress on lasers in dentistry, 4, 287-291, 1994. 
51. Mello JB; Pelino JEP; L'astorina C; Mello LS. Diagnóstico e Prevenção. In: Mello, J. B.; Mello, G. P. S. Laser em Odontologia, 174p., Santos Editora, 2001.

52. Mello, J. B.; Mello, G. P. S. Laser em Odontologia, 174p., Santos Editora, 2001.

53. Myers, ML. The effect of laser irradiation on oral tissues. J Prosthet Dent, v.66, n.3, 395-397, 1991.

54. Myers, TD; McDaniel, JD. The pulsed Nd:YAG dental laser: review of clinical applications. J Calif Dent Assoc, v.19, n.11, 25-30, 1991.

55. Pardi V; Mialhe FL; Pereira AC; Meneghim M de C. Avaliação in vitro do aparelho DIAGNOdent para diagnóstico oclusal. Pesqui Odontol Bras, v.14, n.4, p.372-377, 2000.

56. Picosse M. Anatomia Dentária. Sarvier Editora, 4 ${ }^{\mathrm{a}}$. ed., 216p., 1983.

57. Ribeiro AC. Diagnóstico da cárie de esmalte artificial através da fluorescência induzida por luz. Dissertação de Mestrado, 78p., Recife-PE, 2001.

58. Shi X-Q; Tranæus $S$; Angmar-Månsson B. Comparison of QLF and DIAGNOdent for quantification of smooth surface caries. Caries Res, 35, 21-26, 2001.

59. Shi $X-Q$; Welander U; Angmar-Mảnsson B. Occlusal caries detection with KaVo DIAGNOdent and radiography: an in vitro comparison. Caries Res, 34, 151-158, 2000.

60. Sicher $\mathrm{H}$; Tandler J. Anatomia para Dentistas. Traduzido por Milton Picosse. Atheneu Editora, 416p., 1981.

61. Silverstone LMT. The stucture of carious enamel, including the early lesion. Oral Sci Rev, 3, 1000-160,1973.

62. Skoog DA; West DM; Holler FJ. Fundamentals of Analytical Chemistry, Saunders College Publishing, p.601-610, $7^{\text {th }}$ edition, 1997.

63. Stern, RH; Sognnaes, RF. Laser beam effect on dental tissues. J Dent Res, v.43, n.5, p.873, 1964.

64. Stookey GK; Isaacs RL; Zandona AF; Ando M; Gonzalez C; Mau MS; Kelly S A; Analoui $M$. Clinical validation of the use of fluorescence for the early detection of dental caries. SPIE, v.3593, p.154-157, 1999.

65. Sundström F; Fredriksson K; Montán S; Hafström-Björkman U; Ström J. Laserinduced fluorescence from sound and carious tooth substance: spectroscopic studies. Swed Dent J, 9, 71-80, 1985.

66. Takamori $\mathrm{K}$; Hokari $\mathrm{N}$; Okumura $\mathrm{Y}$; Watanabe $\mathrm{S}$. Detection of occlusal caries under sealants by use of a laser fluorescence system. Journal of Clinical Laser Medicine \& Surgery, v.19, n.5, p.267-271, 2001. 
67. Ten Cate AR. Histologia Bucal. Desenvolvimento, Estrutura e Função. Editora

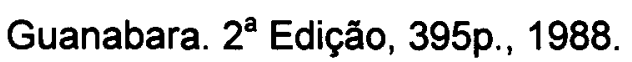

68. Tovo MF; Vono BG; Tavano O. Comparação entre filmes radiográficos e o sistema digital Digora, no diagnóstico de lesões de cárie dentinária em superfície proximal de molares decíduos. Pesqui Odontol Bras, v.14, n4, p.399405, 2000.

69. Tseng, $P$ et al. The bactericidal effect of a Nd:YAG laser in vitro. J Dent Res, v.70, n.4, (Abstract), 1991.

70. Van der Veen MH; Ten Bosch JJ. A fiber-optic setup for quantification of root surface demineralization. Eur J Oral Sci, 104, 118-122, 1996a.

71. Van der Veen MH; Ten Bosch JJ. Autofluorescence of bulk sound and in vitro demineralized human root dentin. Eur J Oral Sci, 103, 375-381, 1995.

72. Van der Veen $M H$; Ten Bosch JJ. The influence of mineral loss on the autofluorescent behaviour of in vitro demineralised dentine. Caries Res, 30, 93-99, 1996b.

73. White, JM; Goodis, HE. Histologic effects of a high-repetition pulsed Nd:YAG laser on intraoral soft tissue. SPIE, v.2394, 143-153, 1995.

74. White, JM; Goodis, HE; Rose, CL. Use of the pulsed Nd:YAG laser for intraoral soft tissue surgery. Lasers Surg Med, v.11, 455-461, 1991.

75. Yassin OM. In vitro studies of the effect of a dental explorer on the formation of an artificial carious lesion. ASDC Journal of Dentistry for Children, 62, 111-117, 1995.

76. Zandoná, AGF. Detection of demineralization on occlusal pit and fissures. Indiana, 1997, 155p. Thesis (Doctor of Philosophy) - School of Dentistry, Indiana University.

77. Zanin F; Pinheiro A; Campos DHS; Brugnera Jr A; Pécora JD. Caries diagnosis using laser fluorescence. SPIE, v.3910, 290-296, 2000. 